Article

\title{
Discovery of Novel 3-Cyanopyridines as Survivin Modulators and Apoptosis Inducers
}

\author{
Rehab Sabour ${ }^{1}$, Marwa F. Harras ${ }^{1, *}$, Omkulthom Mohamed Al Kamaly ${ }^{2}$ and Najla Altwaijry ${ }^{2}$ \\ 1 Department of Pharmaceutical Chemistry, Faculty of Pharmacy (Girls), Al-Azhar University, \\ Cairo 11754, Egypt; rehabsabour.pharmg@azhar.edu.eg \\ 2 Department of Pharmaceutical Sciences, College of Pharmacy, Princess Nourah bint Abdulrahman \\ University, Riyadh 11461, Saudi Arabia; omalkmali@pnu.edu.sa (O.M.A.K.); naaltwaijry@pnu.edu.sa (N.A.) \\ * Correspondence: marwaharras.pharmg@azhar.edu.eg
}

Received: 23 September 2020; Accepted: 21 October 2020; Published: 22 October 2020

check for updates

\begin{abstract}
The overexpression of survivin is usually accompanied by an increased resistance of cancer cells to chemotherapeutic agents in addition to cancer aggressiveness. Consequently, survivin is considered as an attractive target to develop new promising anticancer candidates. A series of novel 3-cyanopyridine derivatives was synthesized and assessed for their cytotoxic activity against three human cancer cell lines: prostate carcinoma (PC-3), breast cancer (MDA-MB-231) and hepatocellular carcinoma (HepG2). In addition, their activities were evaluated in comparison with a standard anticancer drug 5-FU. Compounds $\mathbf{5} \mathbf{c}$ and $\mathbf{5 e}$ both exhibited promising cytotoxicity against all the tested cell lines; especially, 5e showed better cytotoxic effect than the reference drug 5-FU. In order to evaluate the safety of these compounds, they were tested on the normal cell line WI-38, revealing their toxic selectivity toward cancer cells over normal ones. Further studies were performed in order to understand their mechanism of action; we examined the ability of our promising compounds $\mathbf{5 c}$ and $5 \mathbf{e}$ to induce cell cycle arrest. Both resulted in a notable induction of cell cycle arrest at the G2/M phase, along with an increase in the DNA content in the pre-G1 phase, giving us an indication of the incidence of apoptosis. $5 \mathrm{c}$ and $5 \mathrm{e}$ were further subjected to additional study using Annexin V-FITC assay in order to evaluate their ability to induce apoptosis. The results showed a marked increase in the early and late apoptotic cells, as well as an increase in the percentage of necrosis. Furthermore, Western blotting assay was accomplished using different concentrations of $5 \mathbf{c}$ and $\mathbf{5 e}$. The results revealed a striking reduction in survivin expression through proteasome-dependent survivin degradation in addition to a decrease in the expression of some other inhibitor of apoptosis proteins (IAP) family proteins: Livin, XIAP, and C-IAP1 in a concentration-dependent manner. A docking study of $\mathbf{5 c}$ and 5e compounds in the dimerization site of survivin was also performed, showing agreement with the in vitro anti-survivin activity.
\end{abstract}

Keywords: 3-cyanopyridine; synthesis; anticancer; cell cycle arrest; apoptosis; survivin

\section{Introduction}

Cancer is considered a major global disease and a leading cause of death all over the world. It is estimated that more than 1.8 million new cases of cancer will be diagnosed in 2020. The great incidence of cancer around the world encouraged searching for safer and more efficient anticancer drugs via designing new candidates possessing great selectivity on the desired target $[1,2]$. The growth as well as conservation of many adult tissues is attained by numerous dynamically regulated processes, including cell propagation, differentiation, and ordered programmed cell death (apoptosis) [3].

Apoptosis represents the genetic program of cell death, which is a process that is essential to maintain the cell number homeostasis of tissues and organs throughout life. The deregulation of 
apoptosis is considered a pathogenic aspect of different diseases. Moreover, increased cell survival is one of the tumor hallmarks [4]. There are many studies that prove the great relationship between increased resistance to chemotherapy and the declined capacity to go through apoptosis [5]. To date, chemotherapy resistance is considered an obstacle in the management of cancer, where many of the primarily responsive tumors setback and develop resistance to different chemotherapeutic agents. Accordingly, the synthesis of new agents having low liability to drug resistance mechanisms is urgently needed for the management and treatment of various forms of cancer. In the last few years, there was tangible progress in the development of cytotoxic therapies used clinically based on their ability to induce cell death programs such as apoptosis [6].

Inhibitor of apoptosis proteins (IAPs) are a family of antiapoptotic proteins that have the ability to inhibit the death of cells via modulating cellular division, cell cycle progress, and controlling signal transduction pathways. Owing to the fact that they are preferentially expressed in malignant cells and are prognostically important, they are considered as attractive therapeutic goals; hence, great efforts are in progress to develop chemical IAP inhibitors that might be valuable for the treatment of different tumors [7].

Survivin, as a member of the inhibitor of apoptosis (IAP) family, plays a vital role in both the inhibition of apoptosis and regulation of the cell cycle. It is a 16.5-kDa homodimeric cytoplasmic protein, which increases in the G2/M phase of the cell cycle followed by a rapid drop in the G1 phase; therefore, it plays an important role in mitotic cell division where it shows cell cycle-dependent expression, with a distinct accumulation at mitosis. Concerning its behavior, crystallographic studies revealed that it forms homodimers across the interface of dimerization. In addition, this dimeric structure is stabilized by the formation of non-polar connections between residues, which are mostly hydrophobic. It is overexpressed in many tumor cells accompanied by cancer cell resistance to chemotherapy and radiotherapy, cancer cell metastasis, poor prognosis, and the extremely shorter survival rates of patients. Therefore, it is considered as a cancer-specific biomarker. Hence, targeting survivin embodies an attractive strategy for the development of more selective anticancer therapeutics [8-16].

Recently, several strategies have been established to hinder the expression of survivin, among which the use of small molecules inhibitors is included. The development of new inhibitors that interact directly with the protein is considered a great challenge, since survivin is characterized by having no catalytic activity or natural ligands, and its role is mediated via protein-protein interactions [17].

Different scaffolds have been reported that significantly suppress the expression of survivin. Interestingly, several studies in the literature have reported the effectiveness of the 3-cyanopyridine scaffold as an important survivin inhibitor. Consequently, it is considered as an encouraging template for designing a new category of chemotherapeutics [18,19]. Moreover, the dimerization interface has been reported to accommodate small molecules such as Abbott8. It is the prototype of a 3-cyanopyridine-based small molecule that binds at survivin's dimerization interface [20]. In addition, structurally related analogs of Abbott8 (LLP3, LLP9) (Figure 1) were also reported for their anti-survivin activity. The effect of LLP3 analog on delaying mitotic progression and interference with the function of survivin in cell proliferation against two isogenic glioma cell lines was observed as it binds at the dimerization interface [21,22]. Furthermore, 3-cyano-4, 6-diaryl-2-pyridone derivatives I and II have been reported for their anti-survivin activities. It was observed that the affinity of compound I to survivin was enhanced via improving lipophilicity by introducing two halogen atoms to the phenyl ring at position 4 of the pyridine ring in compound II [23]. 
<smiles>[R20]c1ccc([R])c(-c2cc(-c3cc(Br)ccc3O)cc([R2])c2-c2ccc(O)c(-c3cc(-c4ccccc4)c(C#N)c(=O)[nH]3)c2)c1</smiles>

Figure 1. Reported 3-cyanopyridine derivatives as survivin inhibitors.

Encouraged by the above-mentioned findings and in continuation of our efforts [24] to discover and develop new compounds that act as effective anti-survivin chemotherapeutic agents, novel derivatives of 3-cyano pyridines were designed and synthesized to study their in vitro anti-tumor activities.

In the present study, the anti-tumor activity of the newly synthesized compounds was examined against three cell lines: prostate cancer cell line (PC-3), breast cancer cell line (MDA-MB-231), and liver cancer cell line (HepG2). Cell cycle analysis was performed along with Western blotting in order to study the mechanism of the cytotoxicity of the most active compounds.

\section{Results and Discussion}

\subsection{Chemistry}

The synthesis of the target 3-cyano pyridine derivatives is described in Scheme 1 . The starting chalcones 3a-3e were prepared in high yields by Claisen-Schmidt condensation [25,26] of 4-fluorobenzyloxyacetophenone with benzaldehyde/substituted benzaldehydes. The structures of these chalcones were confirmed based on their spectral and elemental analysis. The condensation reaction of chalcones $\mathbf{3 a - 3 e}$ with malononitrile and ammonium acetate in ethanol solvent [27] yielded 2-amino cyanopyridines $4 \mathbf{a}-\mathbf{4 e}$. The IR spectrum of $\mathbf{4 a - 4 e}$ revealed sharp bands at $2214-2219 \mathrm{~cm}^{-1}$ 
corresponding to the nitrile function and displayed bands at $3348-3206 \mathrm{~cm}^{-1}$ representing the amino group absorption. Additionally, as an example, the ${ }^{1} \mathrm{H}-\mathrm{NMR}$ spectrum of 4 a showed singlets at 5.16 and $8.40 \mathrm{ppm}$ for the $\mathrm{O}-\mathrm{CH}_{2}$ and pyridine ring $\mathrm{H}-5$, respectively as well as a singlet at $\delta 6.14 \mathrm{ppm}$ exchanged with $\mathrm{D}_{2} \mathrm{O}$ assigned to $\mathrm{NH}_{2}$ protons.

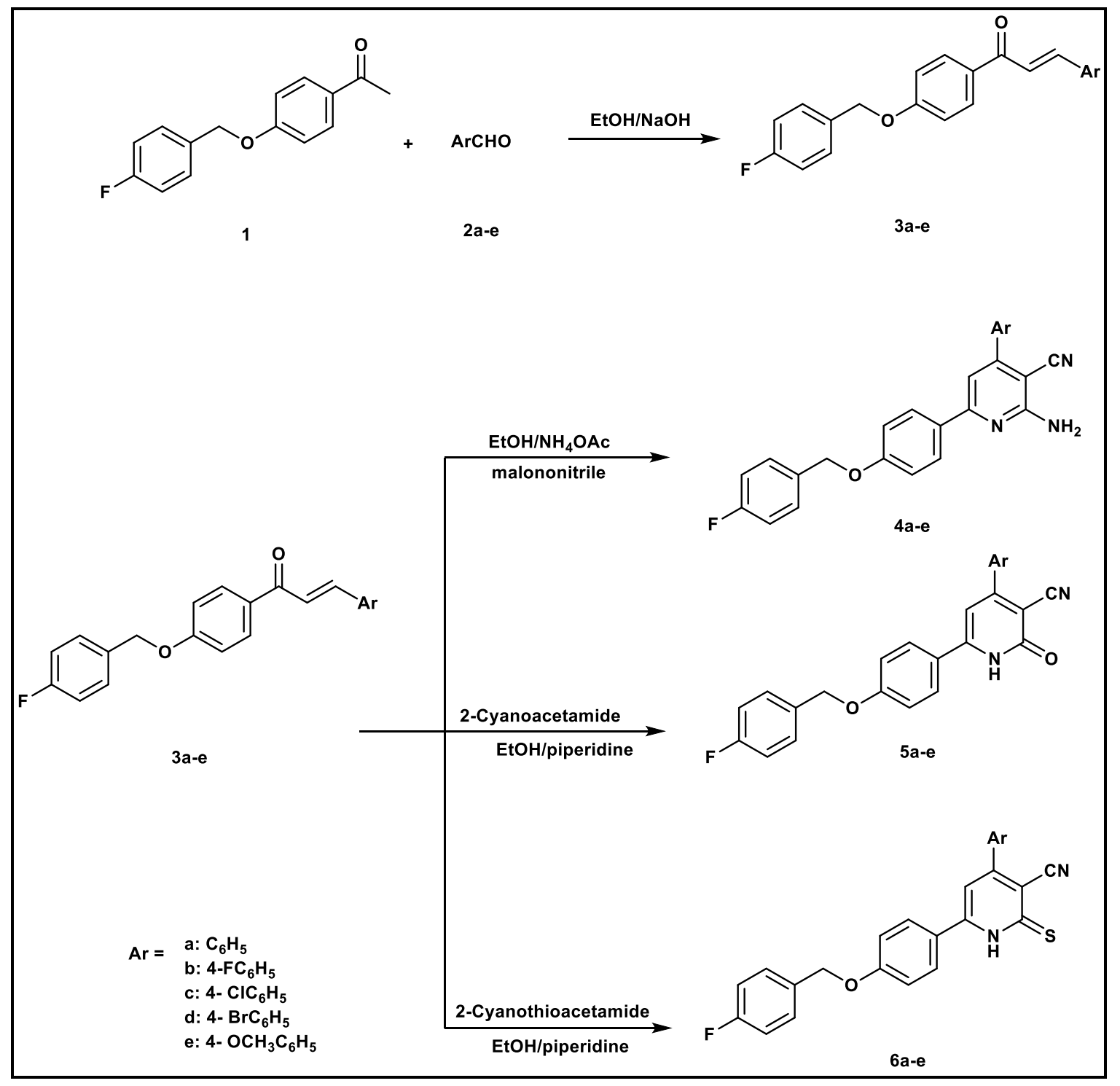

Scheme 1. Synthetic pathway of compounds 3-6.

On the other hand, 2-oxo-3-cyano pyridines 5a-5e and 2-thioxo-3-cyano pyridines 6a-6e were synthesized by the condensation of chalcones 3a-3e with 2-cyanoacetamide and 2-cyanothioacetamide in ethanol/piperidine [28].

The proposed structures of $\mathbf{5 a - 5 e}$ and $\mathbf{6 a}-\mathbf{6 e}$ were established by microanalytical measurements. Their IR spectra presented absorption bands at $3201-3378 \mathrm{~cm}^{-1}$ comprising NH groups in addition to absorption bands at 2206-2222 $\mathrm{cm}^{-1}$ assigned to the nitrile group. Furthermore, the carbonyl function of compounds $5 \mathbf{a}-\mathbf{5 e}$ appeared as strong bands in the range of $1643-1658 \mathrm{~cm}^{-1}$. The protons of the $\mathrm{O}-\mathrm{CH}_{2}$ group of these compounds appeared as singlet signals at 5.14-5.25 ppm in their 1H-NMR spectra. Another singlet signal was seen at $6.60-6.81 \mathrm{ppm}$ corresponding to $\mathrm{H}-5$ of the pyridine ring for compounds 5a-5e and at 7.47-8.03 ppm for compounds 6a-6e. The Supplementary Material Figures S1-S36 contain the NMR charts for the synthesized compounds. 


\subsection{Biological Activity}

\subsubsection{Cytotoxicity Evaluation}

In the present work, sulforhodamine B (SRB) colorimetric assay $[29,30]$ was done to evaluate the cytotoxic activity of the synthesized 3-cyano pyridines $\mathbf{4 a - 4 e}, \mathbf{5 a}-\mathbf{5 e}$, and $\mathbf{6 a}-\mathbf{6 e}$ on three human cancer cell lines: prostate carcinoma (PC-3), breast cancer (MDA-MB-231) and hepatocellular carcinoma (HepG2) cell lines. 5-FU was used as a standard drug for comparison. The IC50 value results for the screened compounds are displayed in Table 1.

Table 1. Cytotoxicity of compounds 4-6 and 5-FU evaluated in different human cancer cells. ${ }^{a}$

\begin{tabular}{cccc}
\hline Compound & \multicolumn{3}{c}{ IC $_{\mathbf{5 0}}(\boldsymbol{\mu M})$} \\
\hline $\mathbf{4 a}$ & $>100$ & MDA-MB-231 & HepG2 \\
$\mathbf{4 b}$ & $>100$ & $>100$ & $109 \pm 0.35$ \\
$\mathbf{4 c}$ & $>100$ & $>100$ & $>100$ \\
$\mathbf{4 d}$ & $53 \pm 1.12$ & $>100$ & $62 \pm 0.61$ \\
$\mathbf{4 e}$ & $>100$ & $30 \pm 0.18$ & $66 \pm 0.12$ \\
$\mathbf{5 a}$ & $47.5 \pm 0.611$ & $>100$ & $>100$ \\
$\mathbf{5 b}$ & $34.2 \pm 0.45$ & $26.34 \pm 0.40$ & $30 \pm 0.59$ \\
$\mathbf{5 c}$ & $14.4 \pm 0.38$ & $20 \pm 0.17$ & $21.81 \pm 0.67$ \\
$\mathbf{5 d}$ & $30.24 \pm 0.85$ & $34.83 \pm 0.90$ & $15 \pm 0.64$ \\
$\mathbf{5 e}$ & $4.46 \pm 0.51$ & $3.59 \pm 0.42$ & $6.01 \pm 0.53$ \\
$\mathbf{6 a}$ & $>100$ & $72 \pm 0.52$ & $60 \pm 0.10$ \\
$\mathbf{6 b}$ & $60 \pm 0.93$ & $66.7 \pm 0.12$ & $41 \pm 0.69$ \\
$\mathbf{6 c}$ & $41.89 \pm 0.61$ & $42 \pm 0.48$ & $38 \pm 0.94$ \\
$\mathbf{6 d}$ & $99 \pm 0.19$ & $71.2 \pm 0.56$ & $86 \pm 0.15$ \\
$\mathbf{6 e}$ & $35.9 \pm 0.92$ & $23.45 \pm 0.70$ & $40.31 \pm 0.99$ \\
$\mathbf{5 - F U}$ & $8.83 \pm 0.09$ & $9.35 \pm 0.74$ & $7.51 \pm 0.11$ \\
\hline
\end{tabular}

a The cytotoxic activity of compounds on the cancer cell lines determined using the sulforhodamine B (SRB) assay. The data are expressed as the mean \pm SD of three independent experiments.

Skimming the cytotoxicity results of compounds $4 \mathbf{a}-4 \mathbf{e}$ revealed poor activities with the exception of the bromo derivative $4 \mathrm{~d}$, which was the only derivative that showed moderate cytotoxicity $\left(\mathrm{IC}_{50}=\right.$ 53,30 , and $66 \mu \mathrm{M}$ against PC-3, MDA-MB-231, and HepG2, respectively).

Concerning the 2-oxo-3-cyanopyridines 5a-5e, significant anti-proliferative activities were observed. Compound $\mathbf{5 e}$ with 4-methoxy substitution was the most active among all tested compounds. It showed twice the activity of 5-FU against the PC-3 cell line, 2.6-fold the activity against MDA-MB-231, and it was comparable to 5-FU against HepG2. In addition, the chloro derivative $5 \mathrm{c}$ exhibited promising cytotoxicity that was nearly half that of 5-FU. Additionally, the rest of the 2-oxo-3-cyanopyridine derivatives revealed moderate anti-tumor activities with $\mathrm{IC}_{50}$ values ranging from 27.2 to $52 \mu \mathrm{M}$.

On the other hand, 2-thioxo-3-cyanopyridine derivatives 6a-6e showed moderate potencies. The methoxy derivative $6 \mathbf{e}$, being the best of these compounds, displayed $\mathrm{IC}_{50}=35.9,23.4$, and 40.3 against PC-3, MDA-MB-231, and HepG2, respectively.

Studying the SAR of our new 3-cyano pyridine derivatives revealed that in general, the 2-oxo-3-cyanopyridine scaffold is preferred for the in vitro cytotoxic activity compared to the 2-thioxo-3-cyanopyridine and 2-amino-3-cyanopyridine scaffolds. In addition, it was observed that the substituted phenyl moiety in the 4th position of the pyridine ring is more affirmative for the anti-proliferative activity than the unsubstituted phenyl group.

The cytotoxicity of the newly synthesized compounds on the normal cell line WI-38 was also evaluated in order to examine the safety of these compounds. The results revealed $\mathrm{IC}_{50}$ values ranging from 89.62 to $205.64 \mu \mathrm{M}$, revealing the safety of most compounds. Concerning the cytotoxicity of the most potent compounds $\mathbf{5} \mathbf{c}$ and $\mathbf{5 e}$, high $\mathrm{IC}_{50}$ values were observed for both compounds $\left(\mathrm{IC}_{50}=91.29\right.$ 
and $102.57 \mu \mathrm{M}$, respectively) and high selectivity indices (SI $=6.33,4.56,6.08$ for $5 \mathrm{c}$ and 22.99, 28.57, 17.06 for $\mathbf{5 e}$ ), indicating their more selective toxicity toward the cancer cells than normal cells (Table 2).

Table 2. Cytotoxicity of compounds $\mathbf{5} \mathbf{c}$ and $\mathbf{5 e}$ on the normal WI-38 cell line.

\begin{tabular}{|c|c|c|c|c|}
\hline \multirow[t]{2}{*}{ Compound } & \multirow[t]{2}{*}{ WI-38 IC I0 $(\mu \mathrm{M})^{a}$} & \multicolumn{3}{|c|}{ Selectivity Index ${ }^{b}$} \\
\hline & & PC-3 & MDA-MB-231 & HepG2 \\
\hline $4 a$ & $164.25 \pm 4.5$ & - & - & 1.50 \\
\hline $4 b$ & $127.18 \pm 3.6$ & - & - & - \\
\hline $4 c$ & $136.53 \pm 4.15$ & - & - & 2.20 \\
\hline $4 d$ & $103.94 \pm 3.16$ & 1.96 & 3.46 & 1.57 \\
\hline $4 e$ & $94.71 \pm 2.5$ & - & - & - \\
\hline $5 a$ & $174.11 \pm 4.62$ & 3.66 & 3.34 & 5.80 \\
\hline $5 b$ & $131.5 \pm 4.12$ & 3.84 & 4.99 & 6.02 \\
\hline $5 c$ & $91.29 \pm 0.47$ & 6.33 & 4.56 & 6.08 \\
\hline $5 d$ & $181.15 \pm 4.55$ & 5.99 & 5.20 & 6.63 \\
\hline $5 e$ & $102.57 \pm 0.81$ & 22.99 & 28.57 & 17.06 \\
\hline $6 a$ & $97.42 \pm 2.88$ & - & 1.35 & 1.62 \\
\hline $6 b$ & $205.64 \pm 4.73$ & 3.42 & 3.08 & 5.01 \\
\hline $6 c$ & $89.62 \pm 2.75$ & 2.13 & 2.13 & 2.35 \\
\hline $6 d$ & $145.80 \pm 4.55$ & 1.47 & 2.04 & 1.69 \\
\hline $6 e$ & $103.94 \pm 3.16$ & 2.89 & 4.43 & 2.57 \\
\hline 5-FU & $7.91 \pm 1.80$ & 0.89 & 0.84 & 1.05 \\
\hline
\end{tabular}

a The cytotoxic activity of compounds on the cancer cell lines determined using the SRB assay. The data are expressed as the mean $\pm \mathrm{SD}$ of three independent experiments. ${ }^{\mathrm{b}}$ Selectivity index $(\mathrm{SI})=\mathrm{IC}_{50}$ on WI-38/IC 50 on cancer cells

\subsubsection{Cell Cycle Analysis}

Survivin has been recognized to play dual roles in stimulating cell-cycle progression and in obstructing apoptosis [13]. Additionally, survivin is known to be expressed mainly in the G2/M phase of the cell cycle $[8,21]$. Therefore, it was significant to examine the ability of our promising compounds $\mathbf{5 c}$ and $\mathbf{5 e}$ to induce cell cycle arrest. Flow cytometry analysis was carried out on MDA-MB-231 cells after treatment with the $\mathrm{IC}_{50}$ concentrations of $\mathbf{5 c}$ and $\mathbf{5 e}$ for $24 \mathrm{~h}$. As shown in Figure 2 and Table 3, both $5 c$ and $5 e$ caused an increase in the number of cells in the G2/M phase by 4.92 and 5.74 folds, respectively, compared to the control cells. At the same time, a decrease in the DNA content in the G0/G1 phase, and a slight decrease in the S phase cells were observed. Moreover, compounds $\mathbf{5 c}$ and $\mathbf{5 e}$ resulted in a remarkable increase in the pre-G1 apoptotic cells count, giving an indication of apoptosis induction. Supplementary Material Figures S37-S39 contain the cell cycle analysis for control and compounds $5 \mathrm{c}$ and $5 \mathbf{e}$.

Table 3. Results of cell cycle analysis in MDA-MB-231cells expressed by (\%) of cells in each phase after treatment with compounds $5 \mathrm{c}$ and $5 \mathbf{e}$.

\begin{tabular}{ccccc}
\hline Compound & \%G0-G1 & \%S & \%G2-M & \%Pre-G1 \\
\hline 5c & 45.27 & 33.16 & 21.57 & 16.32 \\
5e & 42.36 & 32.48 & 25.16 & 19.47 \\
Control & 60.41 & 35.21 & 4.38 & 1.87 \\
\hline
\end{tabular}




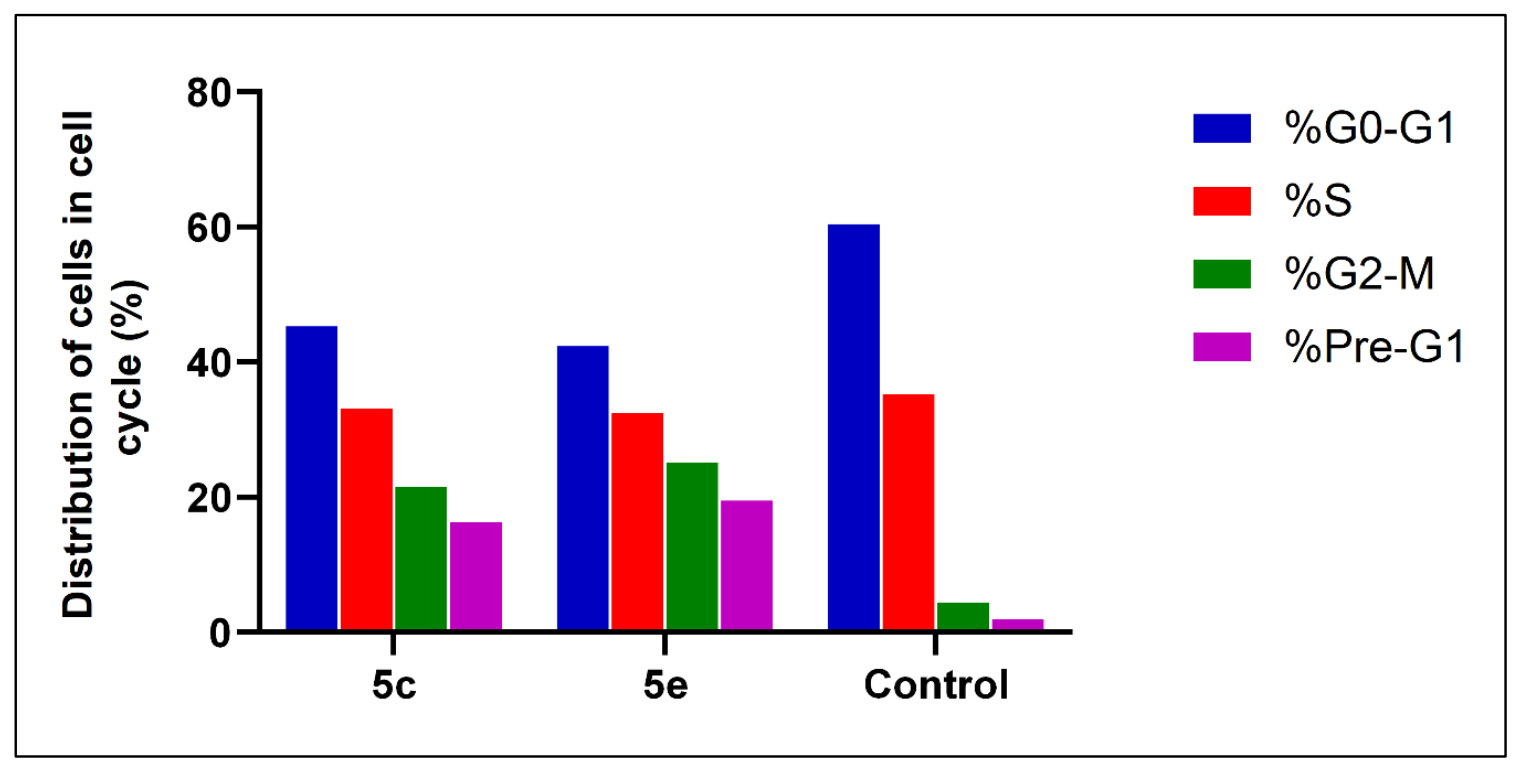

Figure 2. Cell cycle analysis of MDA-MB-231cells after treatment with compounds $\mathbf{5} \mathbf{c}$ and $\mathbf{5 e}$ and DMSO controls. The experiments were done in duplicates.

\subsubsection{Apoptosis Study}

Survivin overexpression markedly decreased both drug-induced and spontaneous apoptosis. So, inhibiting survivin should result in increased spontaneous apoptosis in tumor cells [31]. In this study, the apoptotic potential of $\mathbf{5} \mathbf{c}$ and $\mathbf{5 e}$ was further assessed using Annexin V-FITC assay. The results are shown in Table 4 and Figure 3, displaying a significant increase in the early and late apoptotic cells, in addition to the rise in the percentage of necrosis with a total increase by 8.72 and 10.41 -fold for $5 \mathrm{c}$ and 5e, respectively as compared to the control cells.

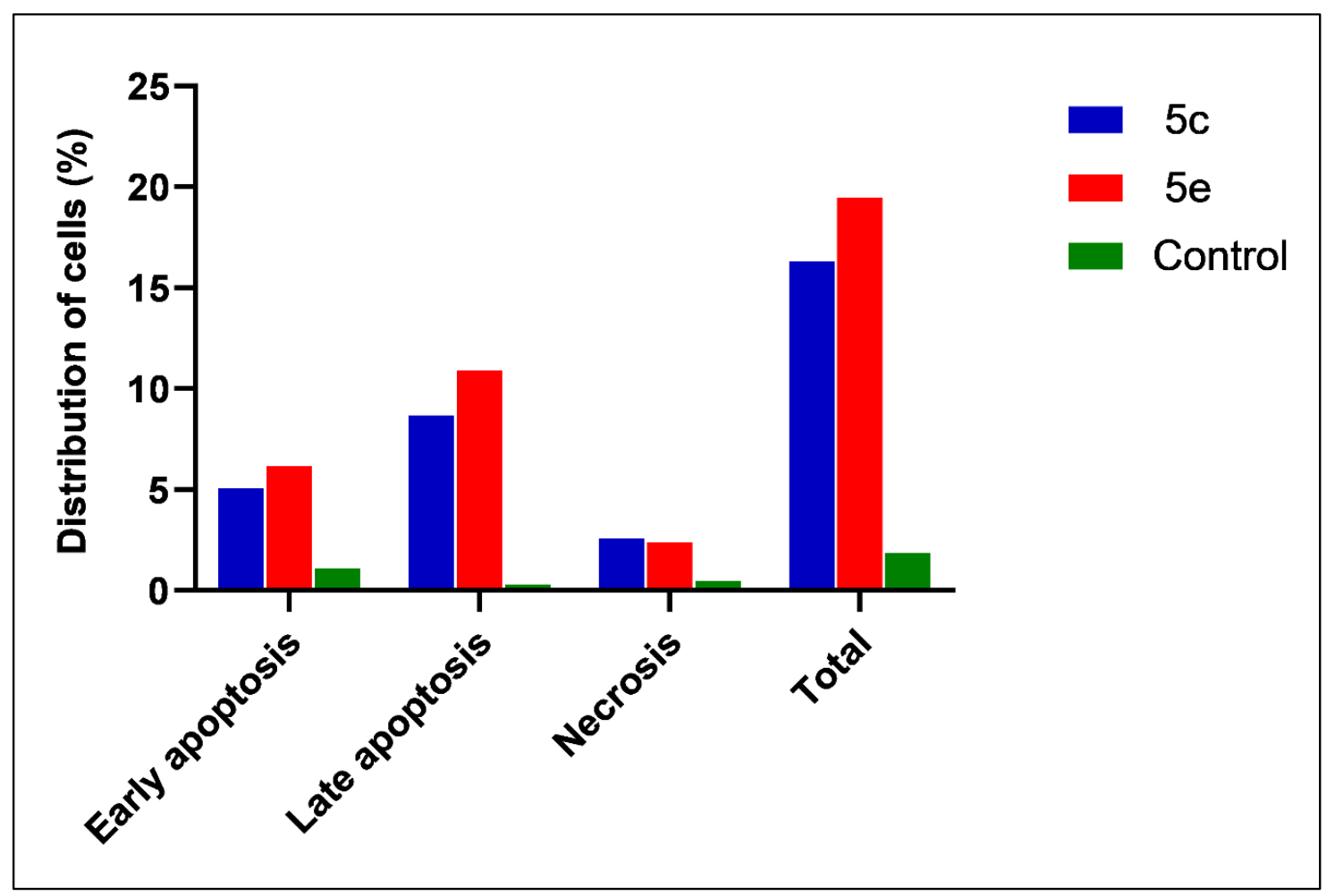

Figure 3. Induction of apoptosis of MDA-MB-231cells after treatment with compounds $5 \mathbf{c}$ and $\mathbf{5 e}$ and DMSO controls. The experiments were done in duplicates. 
Table 4. Percent of cell death induced by compounds 5c and 5e on MDA-MB-231cells.

\begin{tabular}{ccccc}
\hline \multirow{2}{*}{ Compound } & \multicolumn{2}{c}{ Apoptosis } & \multirow{2}{*}{ Necrosis } & Total \\
\cline { 2 - 3 } & Early & Late & & \\
\hline $5 \mathbf{c}$ & 5.07 & 8.67 & 2.58 & 16.32 \\
$5 \mathbf{e}$ & 6.18 & 10.91 & 2.38 & 19.47 \\
Control & 1.09 & 0.31 & 0.47 & 1.87 \\
\hline
\end{tabular}

\subsubsection{Docking Study}

Survivin is a zinc-containing protein consisting of 142 amino acids. Crystallographic studies have revealed that survivin forms homodimers across the dimerization interface that includes the amino acid residues 6-10 and 89-102. This dimeric construction is stabilized through non-polar contacts, mainly hydrophobic interactions, between residues [17,32,33]. By analysis of the dimerization interface, Leu6, Pro7, Pro8, Ala9, Trp10, Phe93, Glu94, Glu95, Leu96, Thr97, Leu98, Gly99, Phe101, and Leu102 were found to interact between the two subunits, forming a dimerization core. This core is formed essentially by the binding of Leu98 and Phe101 from one chain to the same residues of the second chain. Previous studies have indicated that this dimerization core is firmly sealed and thus is crucial for dimer stabilization. It was suggested that exposure to the hydrophobic dimeric interface can lead to conformational changes, which lead to destabilization and disruption of the dimerization core and thus may cause survivin degradation [31,34-36].

Here, a molecular docking study was carried out to predict and score the poses of the protein-ligand binding using survivin monomer (PDB ID: 1E31) [32] by the MOE program [37]. The results are displayed in Table 5 and Figures 4 and 5.

Table 5. The docking results of compounds $5 \mathbf{c}$ and $5 \mathbf{e}$ into the active site of survivin enzyme.

\begin{tabular}{|c|c|c|c|}
\hline Compound & $\begin{array}{c}\text { Docking Score } \\
\text { (kcal/mol) }\end{array}$ & Interacting Residues & Distance $\left(\mathrm{A}^{\circ}\right)$ \\
\hline \multirow{2}{*}{$5 c$} & \multirow{2}{*}{-6.7164} & Thr97 & 3.24 \\
\hline & & Leu98 & 3.39 \\
\hline \multirow{2}{*}{$5 e$} & \multirow{2}{*}{-7.6630} & Thr97 & 3.01 \\
\hline & & Leu98 & 2.76 \\
\hline \multirow{2}{*}{ LLP9 } & \multirow{2}{*}{-8.0721} & Thr97 & 3.26 \\
\hline & & Leu98 & 2.71 \\
\hline $4 a$ & -4.9213 & - & - \\
\hline
\end{tabular}

Results analysis revealed that the top poses of compounds $5 \mathbf{c}$ and $5 \mathbf{e}$ are located mainly in the dimerization core. Similar binding poses were observed for both compounds showing the following interactions in the dimerization interface: (a) hydrogen bonds between the 2-oxocyanopyridine oxygen atom and Thr97 and Leu98 residues; (b) hydrophobic interaction between the 4-aromatic moiety and Phe93 and Glu94; and (c) hydrophobic interactions between the fluorobenzyloxyphenyl moiety and the dimerization core amino acids Leu98 and Phe101 in addition to the hydrophobic residues Pro7 and Trp10.

Docking study of the ligand LLP9 showed the same pattern as $5 \mathbf{c}$ and $5 \mathbf{e}$. The 2-oxocyanopyridine cyano group formed two hydrogen bonds with Thr97 and Leu98. In addition, the phenoxy group formed hydrophobic interactions with Trp10, Leu98, and Phe101, while the phenyl moiety in the 6 position of the pyridine ring was in close contact with Phe93 and Glu94. On the other hand, the docking of compound $\mathbf{4 a}$, as an example of inactive compounds, revealed poor interaction with a lower docking score $(-4.9213 \mathrm{kcal} / \mathrm{mol})$ and a different binding mode. Although the benzyloxy phenyl group was near the Trp10 and Phe101 residues, the cyanopyridine moiety was oriented away from the dimerization site. Additionally, no hydrogen bonds were formed with the active site. 


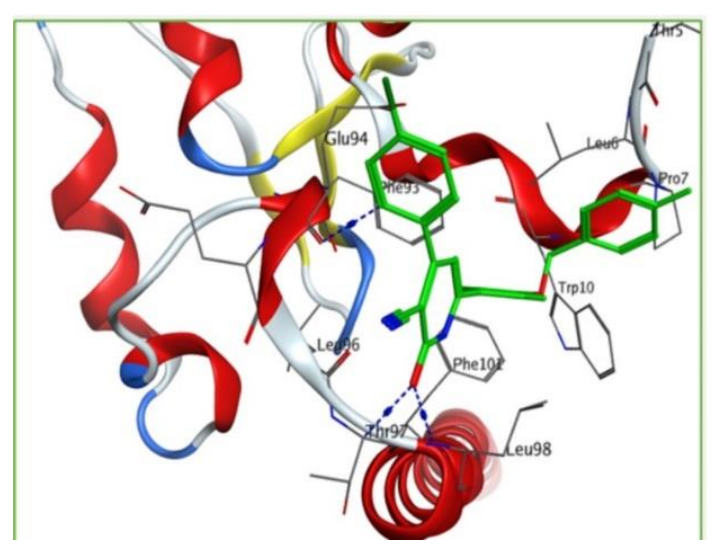

A

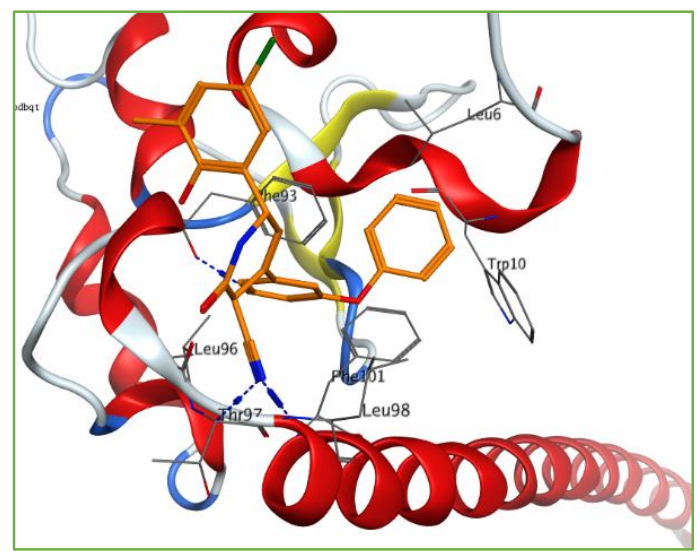

C

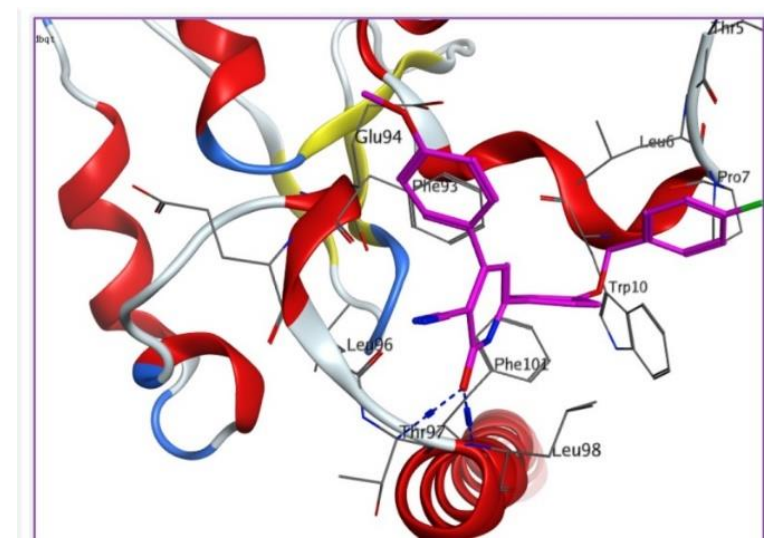

B

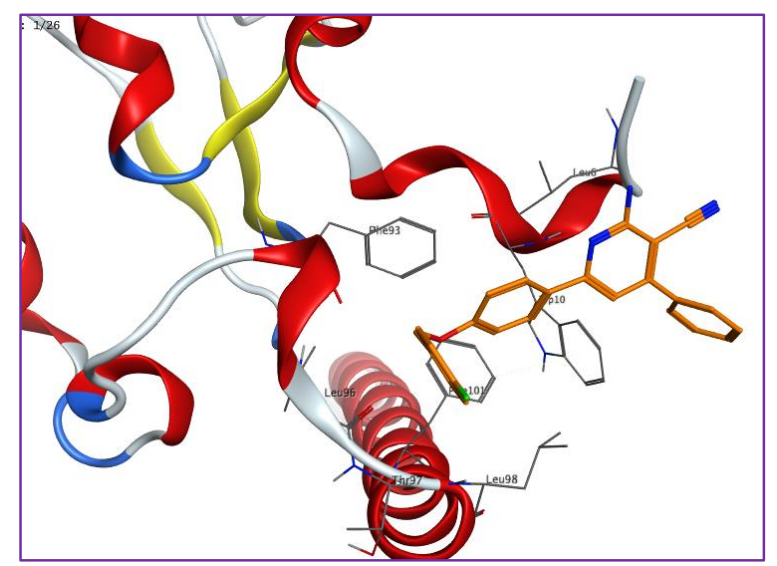

D

Figure 4. The 3D proposed binding mode of compounds 5c (A), 5e (B), LLP9 (C), and 4a (D) docked into the dimerization site of survivin.

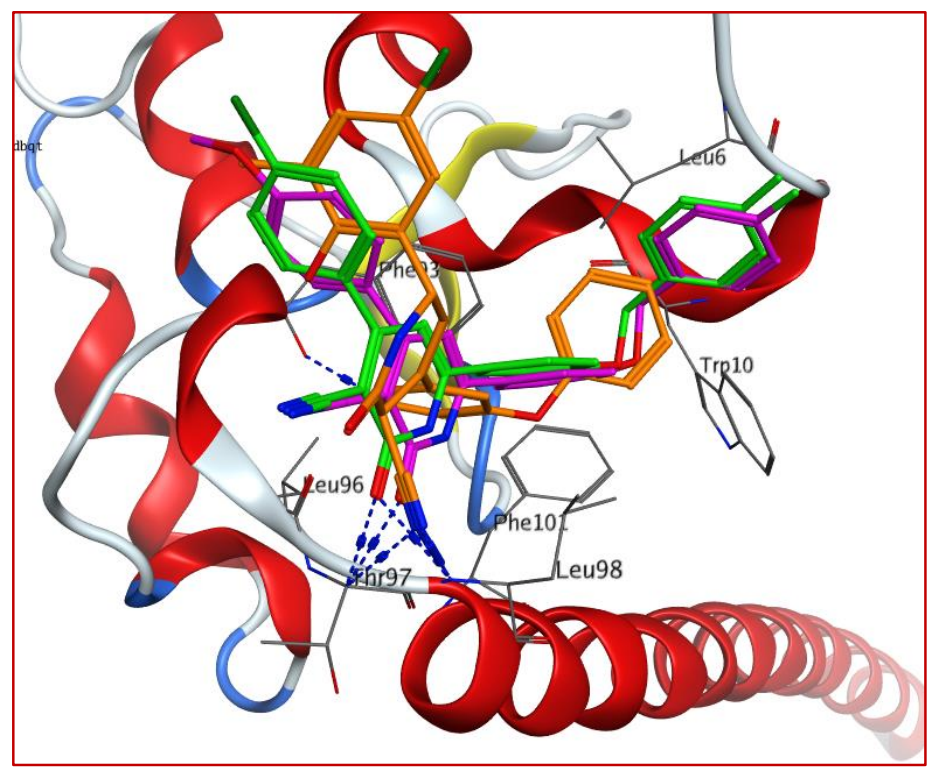

Figure 5. 3D structure overlapping between 5c (in green), 5e (in purple), and LLP9 (in orange) inside the survivin dimerization site. 
These results indicate the possibility of compounds $5 \mathbf{c}$ and $5 \mathbf{e}$ being oriented in the dimerization interface with the proper contacts with the essential core residues, which may be the cause of survivin inhibition.

\subsubsection{Western Blotting Analysis}

The ability of the 2-oxo-3-cyano pyridines $5 \mathbf{c}$ and $\mathbf{5 e}$ to cause an inhibition of survivin was evaluated by the use of Western blotting analysis in MDA-MB-231cells treated with different concentrations of both compounds $(1,5$, and $10 \mu \mathrm{M})$. As represented in Figure 4, a remarkable inhibition of survivin expression was seen in a concentration-dependent manner. Furthermore, to test the effect of these compounds on some other IAP family proteins, the Western plot of Livin, XIAP, and C-IAP1 proteins was performed (Figure 6). The results revealed that $\mathbf{5 c}$ and $5 \mathbf{e}$ decreased the levels of these proteins also, and that decrease is dose-dependent. The Supplementary Material Figures S40 and S41 contain western blotting analysis for $5 \mathbf{c}$ and $5 \mathbf{e}$.

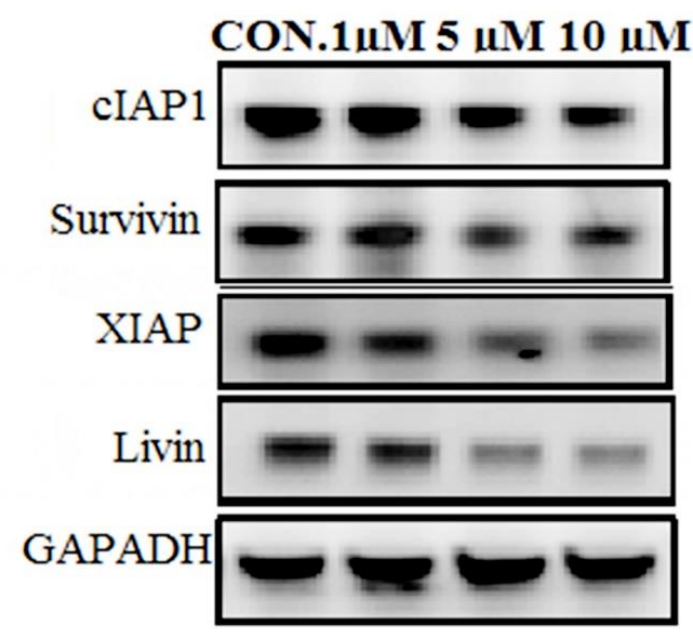

A

Figure 6. Western blot assay of MDA-MB-231 cells treated with different doses of $5 \mathbf{c}(\mathbf{A})$ and $5 \mathbf{e}(\mathbf{B})$ for $24 \mathrm{~h}$.

Degradation of the dimeric proteins can result from the interaction with the hydrophobic dimerization interface, which leads to conformational changes. This degradation can be mediated by the proteasome enzyme [12]. Since $\mathbf{5} \mathbf{c}$ and $\mathbf{5 e}$ were expected to inhibit survivin dimerization as shown in the docking study, we assumed that they may induce the degradation of survivin via the proteasome. Thus, a rescue experiment was performed by pre-treating MDA-MB-cells with the proteasome inhibitor MG132 prior to 5c/5e treatment. As shown in Figure 7, MG132 reversed 5c/5e-induced survivin loss. Thus, $5 \mathrm{c}$ and $5 \mathrm{e}$ likely promote survivin degradation through the proteasome.

\begin{tabular}{|cccccccc|}
\hline $5 c$ & - & + & + & $5 e$ & - & + & + \\
MG132 & - & - & + & MG132 & - & - & + \\
survivin & & & & & & & \\
actin & & & & & & & \\
\hline
\end{tabular}

Figure 7. Western blot assay of MDA-MB-231 showing the effect of proteasome inhibitor MG132 on 5c and 5e-induced survivin degradation. 


\section{Conclusions}

A new series of 3-cyano pyridine derivatives $4 \mathbf{a}-\mathbf{4} \mathbf{e}, \mathbf{5 a}-\mathbf{5 e}$, and $\mathbf{6 a}-\mathbf{6 e}$ were synthesized and their anticancer activity as survivin inhibitors against PC-3, MDA-MB-231, and HepG2 cell lines comparing to $5-\mathrm{FU}$ as a reference drug was evaluated. Two compounds, $5 \mathbf{c}$ and $\mathbf{5 e}$, showed promising activities against all the tested cell lines. In addition, cell cycle arrest was observed at the G2/M phase, indicating a probable induction of apoptosis. The docking study revealed that both compounds were located in the dimerization site with nearly similar binding poses. The Western blotting assay was performed in order to confirm our results, displaying a marked inhibition of different members of IAP family proteins (survivin, Livin, XIAP, and C-IAP1). Furthermore, co-treatment with the proteasome inhibitor MG132 reversed 5c/5e-induced survivin loss.

\section{Materials and Methods}

\subsection{Chemistry}

All melting points were calculated by the Stuart SMP3 Melting Point apparatus utilizing the open capillary tube way. Elemental analysis was done at the Regional Center for Mycology and Biotechnology, Al-Azhar University. IR spectra were measured on a Shimadzu FT/IR 1650 (Perkin Elmer). ${ }^{1} \mathrm{H}-\mathrm{NMR}$ and ${ }^{13} \mathrm{C}-\mathrm{NMR}$ spectra were recorded on an Agilent Technologies $400 \mathrm{MHz} \mathrm{NMR}$ spectrophotometer using TMS as a standard, DMSO as a solvent, and $\mathrm{D}_{2} \mathrm{O}$ for exchangeable $\mathrm{OH}$ and $\mathrm{NH}$ protons. Mass spectra were recorded using a Shimadzu Gas Chromatograph Mass spectrometer-Qp 2010 plus. 1-(4-((4-fluorobenzyl)oxy)phenyl)ethanone (1) was prepared according to the reported procedure [38].

\subsubsection{General Procedure for the Synthesis of Compounds 3a-3e}

A mixture of compound 1 ( $2 \mathrm{mmol})$ and benzaldehyde/substituted benzaldehydes $(2 \mathrm{mmol})$ in $40 \mathrm{~mL}$ of $\mathrm{NaOH}(10 \%)$ in ethanol was stirred for (6-8) h at room temperature. Then, the mixture was poured into ice-cold water that is acidified with $\mathrm{HCl}$. The formed precipitate was filtered off, washed with water, and crystallized from ethanol.

\section{1-(4-((4-Fluorobenzyl)oxy)phenyl)-3-phenylprop-2-en-1-one (3a)}

Yield 85\%; m.p. 118-120 ${ }^{\circ} \mathrm{C}$; IR (KBr, cm $\left.{ }^{-1}\right)$ : 3051 (CH aromatic), 2914 (CH aliphatic), 1657 (CO); ${ }^{1} \mathrm{H}-\mathrm{NMR}$ (DMSO-d6) $\delta$ (ppm): $5.22\left(\mathrm{~s}, 2 \mathrm{H}, \mathrm{OCH}_{2}\right), 7.17(\mathrm{~d}, 2 \mathrm{H}$, aromatic $\mathrm{H}), 7.23-7.57$ (m, 7H, aromatic $\mathrm{H}), 7.72(\mathrm{~d}, 1 \mathrm{H}$, olefinic $\mathrm{H}), 7.89(\mathrm{~d}, 2 \mathrm{H}$, aromatic $\mathrm{H}), 7.96(\mathrm{~d}, 1 \mathrm{H}$, olefinic $\mathrm{H}), 8.19(\mathrm{~d}, 2 \mathrm{H}$, aromatic $\mathrm{H}) ;{ }^{13} \mathrm{C}-\mathrm{NMR}$ (DMSO-d6) $\delta$ (ppm): 69.30, 115.08, 115.29, 115.71, 115.92, 122.43, 129.29, 129.38, 130.60, 130.69, 131.43, 135.28, 143.70, 161.15, 162.70, 163.57, 187.83; MS, m/z: 331 ( $\mathrm{M}^{-1}$, 77.42\%); Anal. Calcd. For $\mathrm{C}_{22} \mathrm{H}_{17} \mathrm{FO}_{2}$ (332.37): C, 79.50; H, 5.16, Found: C, 79.78; H, 5.20.

\section{1-(4-((4-Fluorobenzyl)oxy)phenyl)-3-(4-fluorophenyl)prop-2-en-1-one (3b)}

Yield 80\%; m.p. 138-140 ${ }^{\circ} \mathrm{C}$; IR (KBr, cm $\left.{ }^{-1}\right): 3069$ (CH aromatic), 2914 (CH aliphatic), 1657 (CO); ${ }^{1} \mathrm{H}-\mathrm{NMR}$ (DMSO-d6) $\delta$ (ppm): $5.23\left(\mathrm{~s}, 2 \mathrm{H}, \mathrm{OCH}_{2}\right), 7.17(\mathrm{~d}, 2 \mathrm{H}$, aromatic $\mathrm{H}), 7.24-7.57$ (m, 6H, aromatic $\mathrm{H}), 7.71(\mathrm{~d}, 1 \mathrm{H}$, olefinic $\mathrm{H}), 7.93(\mathrm{~d}, 1 \mathrm{H}$, olefinic $\mathrm{H}), 7.99(\mathrm{~d}, 2 \mathrm{H}$, aromatic $\mathrm{H}), 8.19(\mathrm{~d}, 2 \mathrm{H}$, aromatic H); ${ }^{13}$ C-NMR (DMSO-d6) $\delta$ (ppm): 69.30, 115.29, 115.72, 115.93, 116.28, 116.49, 122.34, 130.62, 130.71, 131.44, 131.60, 131.69, 142.47, 161.14, 162.71, 163.57, 165.03, 187.72; MS, m/z: 350 (M , 70.95\%); Anal. Calcd. For $\mathrm{C}_{22} \mathrm{H}_{16} \mathrm{~F}_{2} \mathrm{O}_{2}$ (350.36): C, 75.42; H, 4.60, Found: C, 75.82; H, 4.81 .

\section{3-(4-Chlorophenyl)-1-(4-((4-fluorobenzyl)oxy)phenyl)prop-2-en-1-one (3c)}

Yield 78\%; m.p. 168-170 ${ }^{\circ} \mathrm{C}$; IR (KBr, cm $\left.{ }^{-1}\right)$ : 3067 (CH aromatic), 2914 (CH aliphatic), 1657 (CO); ${ }^{1} \mathrm{H}-\mathrm{NMR}$ (DMSO-d6) $\delta$ (ppm): $5.23\left(\mathrm{~s}, 2 \mathrm{H}, \mathrm{OCH}_{2}\right), 7.17(\mathrm{~d}, 2 \mathrm{H}$, aromatic $\mathrm{H}), 7.23-7.55(\mathrm{~m}, 6 \mathrm{H}$, aromatic $\mathrm{H}), 7.69(\mathrm{~d}, 1 \mathrm{H}$, olefinic $\mathrm{H}), 7.94(\mathrm{~d}, 2 \mathrm{H}$, aromatic $\mathrm{H}), 7.99(\mathrm{~d}, 1 \mathrm{H}$, olefinic $\mathrm{H}), 8.19(\mathrm{~d}, 2 \mathrm{H}$, aromatic 
H); ${ }^{13}$ C-NMR (DMSO-d6) $\delta$ (ppm): 69.31, 115.32, 115.72, 115.94, 123.19, 129.41, 130.64, 130.72, 131.02, 131.49, 142.23, 161.21, 162.80, 163.62, 165.03, 187.70; MS, $m / z: 168\left[(\mathrm{M}+2)^{+}, 10.46 \%\right], 366\left(\mathrm{M}^{+}, 32.10 \%\right)$; Anal. Calcd. For $\mathrm{C}_{22} \mathrm{H}_{16} \mathrm{ClFO}_{2}$ (366.81): C, 72.04; H, 4.40, Found: $\mathrm{C}, 71.85 ; \mathrm{H}, 4.28$.

\section{3-(4-Bromophenyl)-1-(4-((4-fluorobenzyl)oxy)phenyl)prop-2-en-1-one (3d)}

Yield 89\%; m.p. 160-162 ${ }^{\circ} \mathrm{C}$; IR ( $\left.\mathrm{KBr}, \mathrm{cm}^{-1}\right)$ : 3063 ( $\mathrm{CH}$ aromatic), 2918 ( $\mathrm{CH}$ aliphatic), 1657 (CO); ${ }^{1} \mathrm{H}-\mathrm{NMR}$ (DMSO-d6) $\delta$ (ppm): $5.23\left(\mathrm{~s}, 2 \mathrm{H}, \mathrm{OCH}_{2}\right), 7.17(\mathrm{~d}, 2 \mathrm{H}$, aromatic $\mathrm{H}), 7.23-7.57(\mathrm{~m}, 6 \mathrm{H}$, aromatic $\mathrm{H}), 7.69(\mathrm{~d}, 1 \mathrm{H}$, olefinic $\mathrm{H}), 7.86(\mathrm{~d}, 2 \mathrm{H}$, aromatic $\mathrm{H}), 8.00(\mathrm{~d}, 1 \mathrm{H}$, olefinic $\mathrm{H}), 8.19(\mathrm{~d}, 2 \mathrm{H}$, aromatic H); ${ }^{13}$ C-NMR (DMSO-d6) $\delta$ (ppm): 69.36, 115.13, 115.32, 115.72, 115.93, 123.24, 130.63, 130.71, 130.98, 131.22, 131.49, 142.23, 162.78, 163.57, 187.73; MS, $m / z:\left[(\mathrm{M}+2)^{+}, 30.14 \%\right], 411\left(\mathrm{M}^{+}, 35.91 \%\right) ;$ Anal. Calcd. For $\mathrm{C}_{22} \mathrm{H}_{16} \mathrm{BrFO}_{2}$ (411.26): C, 64.25; H, 3.92, Found: $\mathrm{C}, 64.34 ; \mathrm{H}, 4.02$.

\section{1-(4-((4-Fluorobenzyl)oxy)phenyl)-3-(4-methoxyphenyl)prop-2-en-1-one (3e)}

Yield 79\%; m.p. 120-122 ${ }^{\circ} \mathrm{C}$; IR ( $\left.\mathrm{KBr}, \mathrm{cm}^{-1}\right)$ : 3064 ( $\mathrm{CH}$ aromatic), 2918 ( $\mathrm{CH}$ aliphatic), 1657 (CO); ${ }^{1} \mathrm{H}-\mathrm{NMR}$ (DMSO-d6) $\delta(\mathrm{ppm}): 3.83\left(\mathrm{~s}, 3 \mathrm{H}, \mathrm{OCH}_{3}\right), 5.23\left(\mathrm{~s}, 2 \mathrm{H}, \mathrm{OCH}_{2}\right), 7.02(\mathrm{~d}, 2 \mathrm{H}$, aromatic $\mathrm{H}), 7.16(\mathrm{~d}$, $2 \mathrm{H}$, aromatic $\mathrm{H}), 7.24-7.57(\mathrm{~m}, 4 \mathrm{H}$, aromatic $\mathrm{H}), 7.68(\mathrm{~d}, 1 \mathrm{H}$, olefinic $\mathrm{H}), 7.82(\mathrm{~d}, 1 \mathrm{H}$, olefinic $\mathrm{H}), 7.86(\mathrm{~d}$, $2 \mathrm{H}$, aromatic $\mathrm{H}), 8.16(\mathrm{~d}, 2 \mathrm{H}$, aromatic $\mathrm{H}) ;{ }^{13} \mathrm{C}-\mathrm{NMR}$ (DMSO-d6) $\delta$ (ppm): 55.85, 69.27, 114.86, 115.23, 115.72, 115.93, 119.90, 127.91, 130.62, 130.70, 131.19, 131.27, 131.33, 143.69, 161.14, 161.70, 162.52, 187.70; MS, $m / z: 362\left(\mathrm{M}^{+}, 24.18 \%\right)$; Anal. Calcd. For $\mathrm{C}_{23} \mathrm{H}_{19} \mathrm{FO}_{3}$ (362.39): $\mathrm{C}, 76.23 ; \mathrm{H}, 5.28$, Found: $\mathrm{C}, 76.14 ; \mathrm{H}$, 5.13 .

\subsubsection{General Procedure for the Synthesis of Compounds $4 \mathbf{a}-4 \mathbf{e}$}

A mixture of chalcones $3 \mathbf{a}-3 \mathbf{e}(3 \mathrm{mmol})$, malononitrile $(3 \mathrm{mmol})$, and ammonium acetate $(9 \mathrm{mmol})$ in $20 \mathrm{~mL}$ of absolute ethanol was refluxed for $6 \mathrm{~h}$. Then, the product was precipitated out. The reaction mixture was allowed to cool, and the formed precipitate was filtered, washed with ethanol, dried, and crystallized from ethanol.

\section{2-Amino-6-(4-((4-fluorobenzyl)oxy)phenyl)-4-phenylnicotinonitrile (4a)}

Yield 60\%; m.p. $122-125{ }^{\circ} \mathrm{C}$; IR $\left(\mathrm{KBr}, \mathrm{cm}^{-1}\right)$ : 3298, $3209\left(\mathrm{NH}_{2}\right), 3074(\mathrm{CH}$ aromatic), $2931(\mathrm{CH}$ aliphatic), $2216(\mathrm{CN}) ;{ }^{1} \mathrm{H}-\mathrm{NMR}$ (DMSO-d6) $\delta(\mathrm{ppm}): 5.16\left(\mathrm{~s}, 2 \mathrm{H}, \mathrm{OCH}_{2}\right), 6.14\left(2 \mathrm{H}, \mathrm{NH}_{2}\right.$; exchangeable with $\left.\mathrm{D}_{2} \mathrm{O}\right), 7.09-8.27(\mathrm{~m}, 13 \mathrm{H}, 13$ aromatic $\mathrm{H}), 8.40\left(\mathrm{~s}, 1 \mathrm{H}, \mathrm{CH}\right.$ of pyridine); ${ }^{13} \mathrm{C}-\mathrm{NMR}$ (DMSO-d6) $\delta$ (ppm): 69.08, 81.96, 114.37, 114.49, 114.57, 115.10, 115.23, 115.28, 115.42, 115.50, 115.91, 129.60, 130.61, 130.76, 131.03, 131.25, 133.60, 156.78, 160.14, 161.06, 163.47MS, m/z: $395\left(\mathrm{M}^{+}, 9.69 \%\right)$; Anal. Calcd. For $\mathrm{C}_{25} \mathrm{H}_{18} \mathrm{FN}_{3} \mathrm{O}$ (395.43): C, 75.93; H, 4.59; N, 10.63, Found: C, 75.80; H, 4.61; N, 10.58 .

\section{2-Amino-6-(4-((4-fluorobenzyl)oxy)phenyl)-4-(4-fluorophenyl)nicotinonitrile (4b)}

Yield 53\%; m.p. $125-127^{\circ} \mathrm{C}$; IR $\left(\mathrm{KBr}, \mathrm{cm}^{-1}\right)$ : 3325, $3217\left(\mathrm{NH}_{2}\right), 3074(\mathrm{CH}$ aromatic), $2915(\mathrm{CH}$ aliphatic), 2217 (CN); ${ }^{1} \mathrm{H}-\mathrm{NMR}$ (DMSO-d6) $\delta(\mathrm{ppm}): 5.16\left(\mathrm{~s}, 2 \mathrm{H}, \mathrm{OCH}_{2}\right), 6.77\left(2 \mathrm{H}, \mathrm{NH}_{2}\right.$; exchangeable with $\left.\mathrm{D}_{2} \mathrm{O}\right), 6.94-8.30(\mathrm{~m}, 12 \mathrm{H}, 12$ aromatic $\mathrm{H}), 8.33$ (s, $1 \mathrm{H}, \mathrm{CH}$ of pyridine); ${ }^{13} \mathrm{C}-\mathrm{NMR}$ (DMSO-d6) $\delta$ (ppm): 69.17, 82.70, 114.96, 115.26, 115.60, 115.67, 115.80, 115.84, 117.35, 129.10, 129.17, 1130.35, 130.59, 130.62, 132.07, 132.65, 132.90, 134.17, 157.91, 159.07, 160.32, 161.15; MS, m/z: 413 (M+ $4.16 \%)$; Anal. Calcd. For $\mathrm{C}_{25} \mathrm{H}_{17} \mathrm{~F}_{2} \mathrm{~N}_{3} \mathrm{O}$ (413.42): C, 72.63; H, 4.14; N, 10.16, Found: $\mathrm{C}, 72.52 ; \mathrm{H}, 4.30 ; \mathrm{N}, 10.09$.

\section{2-Amino-4-(4-chlorophenyl)-6-(4-((4-fluorobenzyl)oxy)phenyl)nicotinonitrile (4c)}

Yield 62\%; m.p. $220-222{ }^{\circ} \mathrm{C}$; IR ( $\left.\mathrm{KBr}, \mathrm{cm}^{-1}\right)$ : 3348, $3206\left(\mathrm{NH}_{2}\right), 3064(\mathrm{CH}$ aromatic), $2977(\mathrm{CH}$ aliphatic), 2219 (CN); ${ }^{1} \mathrm{H}-\mathrm{NMR}$ (DMSO-d6) $\delta(\mathrm{ppm}): 5.19\left(\mathrm{~s}, 2 \mathrm{H}, \mathrm{OCH}_{2}\right), 6.29\left(2 \mathrm{H}, \mathrm{NH}_{2}\right.$; exchangeable with $\left.\mathrm{D}_{2} \mathrm{O}\right), 7.09-8.15(\mathrm{~m}, 12 \mathrm{H}$, aromatic $\mathrm{H}), 8.22\left(\mathrm{~s}, 1 \mathrm{H}, \mathrm{CH}\right.$ of pyridine); ${ }^{13} \mathrm{C}-\mathrm{NMR}$ (DMSO-d6) $\delta$ (ppm): 69.18, 90.94, 115.10, 115.23, 115.63, 115.68, 115.85, 115.90, 129.16, 130.53, 130.62, 130.95, 137.18, 154.27, 156.90, 160.38, 162.51; MS, m/z: 431 [(M+2) $\left.{ }^{+}, 3.46 \%\right], 429\left(\mathrm{M}^{+}, 7.81 \%\right)$; Anal. Calcd. For $\mathrm{C}_{25} \mathrm{H}_{17} \mathrm{ClFN}_{3} \mathrm{O}$ (429.87): C, 69.85; H, 3.99; N, 9.77, Found: C, 70.00; H, 3.87; N, 9.84. 


\section{2-Amino-4-(4-bromophenyl)-6-(4-((4-fluorobenzyl)oxy)phenyl)nicotinonitrile (4d)}

Yield 69\%; m.p. $65-67{ }^{\circ} \mathrm{C}$; IR $\left(\mathrm{KBr}, \mathrm{cm}^{-1}\right)$ : 3338, $3212\left(\mathrm{NH}_{2}\right), 3070(\mathrm{CH}$ aromatic), $2979(\mathrm{CH}$ aliphatic), 2219 (CN); ${ }^{1} \mathrm{H}-\mathrm{NMR}$ (DMSO-d6) $\delta(\mathrm{ppm}): 5.19\left(\mathrm{~s}, 2 \mathrm{H}, \mathrm{OCH}_{2}\right), 6.82\left(2 \mathrm{H}, \mathrm{NH}_{2}\right.$; exchangeable with $\left.\mathrm{D}_{2} \mathrm{O}\right), 7.12-7.56(\mathrm{~m}, 6 \mathrm{H}$, aromatic $\mathrm{H}), 7.69(\mathrm{~s}, 1 \mathrm{H}, \mathrm{CH}$ of pyridine), $7.71-8.23(\mathrm{~m}, 6 \mathrm{H}$, aromatic $\mathrm{H})$; ${ }^{13} \mathrm{C}-\mathrm{NMR}$ (DMSO-d6) $\delta$ (ppm): 69.13, 91.23, 112.85, 114.78, 115.05, 115.58, 115.69, 115.90, 116.32, 128.57, 129.54, 129.88, 130.50, 130.53, 130.65, 131.02, 13.45, 156.22, 157.28, 160.79, 161.20; MS, m/z: $476\left[(\mathrm{M}+2)^{+}\right.$, $1.76 \%], 474\left(\mathrm{M}^{+}, 1.37 \%\right)$; Anal. Calcd. For $\mathrm{C}_{25} \mathrm{H}_{17} \mathrm{BrFN}_{3} \mathrm{O}$ (474.32): $\mathrm{C}, 63.30 ; \mathrm{H}, 3.61 ; \mathrm{N}, 8.86$, Found: $\mathrm{C}$, $63.42 ; \mathrm{H}, 3.64 ; \mathrm{N}, 8.93$.

\section{2-Amino-6-(4-((4-fluorobenzyl)oxy)phenyl)-4-(4-methoxyphenyl)nicotinonitrile (4e)}

Yield 75\%; m.p. $123-125^{\circ} \mathrm{C}$; IR (KBr, cm $\left.{ }^{-1}\right)$ : 3302, $3240\left(\mathrm{NH}_{2}\right), 3070(\mathrm{CH}$ aromatic), $2931(\mathrm{CH}$ aliphatic), $2214(\mathrm{CN}) ;{ }^{1} \mathrm{H}-\mathrm{NMR}$ (DMSO-d6) $\delta(\mathrm{ppm}): 3.84\left(\mathrm{~s}, 3 \mathrm{H}, \mathrm{OCH}_{3}\right), 5.16\left(\mathrm{~s}, 2 \mathrm{H}, \mathrm{OCH}_{2}\right), 6.81(2 \mathrm{H}$, $\mathrm{NH}_{2}$; exchangeable with $\left.\mathrm{D}_{2} \mathrm{O}\right), 6.83-7.52(\mathrm{~m}, 6 \mathrm{H}$, aromatic $\mathrm{H}), 7.65(\mathrm{~s}, 1 \mathrm{H}, \mathrm{CH}$ of pyridine), $7.65-8.20$ $(\mathrm{m}, 6 \mathrm{H}$, aromatic $\mathrm{H}) ;{ }^{13} \mathrm{C}-\mathrm{NMR}$ (DMSO-d6) $\delta(\mathrm{ppm}): 55.83,69.13,91.19,112.76,114.10,114.67,115.57$, $115.64,115.85,116.32,128.55,129.49,129.89,130.53,130.65,131.01,133.42,156.12,157.23,160.76,161.17$, 164.50; MS, $m / z: 425\left(\mathrm{M}^{+}, 2.92 \%\right)$; Anal. Calcd. For $\mathrm{C}_{26} \mathrm{H}_{20} \mathrm{FN}_{3} \mathrm{O}_{2}$ (425.45): C, 73.40; H, 4.74; N, 9.88, Found: C, 73.43; H, 4.60; N, 9.76 .

\subsubsection{General Procedure for the Synthesis of Compounds 5a-5e and $\mathbf{6 a - 6 e}$}

A mixture of chalcones $3 \mathbf{a}-\mathbf{3 e}(3 \mathrm{mmol})$ and cyanoacetamide/cyanothioacetamide ( $3 \mathrm{mmol})$ in 20 $\mathrm{mL}$ of absolute ethanol with few drops of piperdine was heated under reflux for $8 \mathrm{~h}$, cooled, poured on ice-cold water, and acidified with $\mathrm{HCl}$. Then, the precipitated solid was filtered and recrystallized from ethanol.

\section{6-(4-((4-Fluorobenzyl)oxy)phenyl)-2-oxo-4-phenyl-1,2-dihydropyridine-3-carbonitrile (5a)}

Yield 70\%; m.p. 81-83 ${ }^{\circ} \mathrm{C}$; IR ( $\left.\mathrm{KBr}, \mathrm{cm}^{-1}\right)$ : $3240(\mathrm{NH}), 3070$ (CH aromatic), 2931 (CH aliphatic), $2214(\mathrm{CN}), 1643(\mathrm{CO}) ;{ }^{1} \mathrm{H}-\mathrm{NMR}$ (DMSO-d6) $\delta(\mathrm{ppm}): 5.22\left(\mathrm{~s}, 2 \mathrm{H}, \mathrm{OCH}_{2}\right), 6.76(\mathrm{~s}, 1 \mathrm{H}, \mathrm{CH}$ of pyridine), 6.84-8.18 (m, 13H, aromatic $\mathrm{H}), 9.76\left(1 \mathrm{H}, \mathrm{NH}\right.$; exchangeable with $\left.\mathrm{D}_{2} \mathrm{O}\right) ;{ }^{13} \mathrm{C}-\mathrm{NMR}$ (DMSO-d6) $\delta(\mathrm{ppm})$ : 69.26, 114.05, 114.65, 114.85, 115.18, 115.23, 115.63, 115.90, 119.98, 129.48, 129.63, 130.59, 130.74, 131.16, 131.35, 143.70, 161.12, 161.69, 162.51, 162.66, 163.54; MS, $m / z: 396\left(\mathrm{M}^{+}, 31.26 \%\right)$; Anal. Calcd. For $\mathrm{C}_{25} \mathrm{H}_{17} \mathrm{FN}_{2} \mathrm{O}_{2}$ (396.41): C, 75.75; H, 4.32; N, 7.07, Found: C, 75.68; H, 4.27; N, 7.17.

\section{6-(4-((4-Fluorobenzyl)oxy)phenyl)-4-(4-fluorophenyl)-2-oxo-1,2-dihydropyridine-3-carbonitrile} (5b)

Yield 55\%; m.p. 178-179 ${ }^{\circ} \mathrm{C}$; IR ( $\left.\mathrm{KBr}, \mathrm{cm}^{-1}\right)$ : $3201(\mathrm{NH}), 3070$ (CH aromatic), 2931 ( $\mathrm{CH}$ aliphatic), $2222(\mathrm{CN}), 1658(\mathrm{CO}) ;{ }^{1} \mathrm{H}-\mathrm{NMR}$ (DMSO-d6) $\delta(\mathrm{ppm}): 5.20\left(\mathrm{~s}, 2 \mathrm{H}, \mathrm{OCH}_{2}\right), 6.81$ (s, $1 \mathrm{H}, \mathrm{CH}$ of pyridine), 7.01-7.92 (m, 12H, aromatic $\mathrm{H}), 9.83\left(1 \mathrm{H}, \mathrm{NH}\right.$; exchangeable with $\left.\mathrm{D}_{2} \mathrm{O}\right) ;{ }^{13} \mathrm{C}-\mathrm{NMR}$ (DMSO-d6) $\delta(\mathrm{ppm})$ : 69.37, 115.10, 115.49, 115.63, 115.90, 116.15, 116.36, 127.35, 129.99, 130.32, 130.41, 130.60, 130.73, 130.94, 131.23, 131.32, 161.11, 161.18, 162.49, 162.72, 163.57; MS, $m / z$ : $414\left(\mathrm{M}^{+}, 19.56 \%\right)$; Anal. Calcd. For $\mathrm{C}_{25} \mathrm{H}_{16} \mathrm{~F}_{2} \mathrm{~N}_{2} \mathrm{O}_{2}$ (414.40): C, 72.46; H, 3.89; N, 6.76, Found: C, 72.41; H, 4.01; N, 6.84.

\section{4-(4-Chlorophenyl)-6-(4-((4-fluorobenzyl)oxy)phenyl)-2-oxo-1,2-dihydropyridine-3-carbonitrile (5c)}

Yield 75\%; m.p. $122-2124{ }^{\circ} \mathrm{C}$; IR ( $\mathrm{KBr}, \mathrm{cm}^{-1}$ ): $3283(\mathrm{NH}), 3070$ ( $\mathrm{CH}$ aromatic), 2931 (CH aliphatic), $2222(\mathrm{CN}), 1651$ (CO); ${ }^{1} \mathrm{H}-\mathrm{NMR}$ (DMSO-d6) $\delta$ (ppm): 5.19 (s, 2H, $\left.\mathrm{OCH}_{2}\right), 6.80$ (s, $1 \mathrm{H}, \mathrm{CH}$ of pyridine), 7.01-8.20 (m, 12H, aromatic $\mathrm{H}), 9.86\left(1 \mathrm{H}, \mathrm{NH}\right.$; exchangeable with $\left.\mathrm{D}_{2} \mathrm{O}\right) ;{ }^{13} \mathrm{C}-\mathrm{NMR}$ (DMSO-d6) $\delta(\mathrm{ppm})$ : 69.35, 115.16, 115.31, 115.66, 115.69, 115.90, 127.32, 128.92, 129.29, 129.39, 130.12, 130.52, 130.71, 131.02, 131.47, 135.45, 161.12, 161.25, 162.56, 162.76, 163.54; MS, $\mathrm{m} / \mathrm{z}: 432\left[(\mathrm{M}+2)^{+}, 30.87 \%\right], 430\left(\mathrm{M}^{+}, 100.00 \%\right)$; Anal. Calcd. For $\mathrm{C}_{25} \mathrm{H}_{16} \mathrm{ClFN}_{2} \mathrm{O}_{2}$ (430.86): C, 69.69; H, 3.74; N, 6.50, Found: C, 69.86; H, 3.70; N, 6.74 . 
4-(4-Bromophenyl)-6-(4-((4-fluorobenzyl)oxy)phenyl)-2-oxo-1,2-dihydropyridine-3-carbonitrile (5d)

Yield 63\%; m.p. $160-162{ }^{\circ} \mathrm{C}$; IR (KBr, $\left.\mathrm{cm}^{-1}\right)$ : $3218(\mathrm{NH}), 3040$ (CH aromatic), 2929 (CH aliphatic), $2217(\mathrm{CN}), 1643(\mathrm{CO}) ;{ }^{1} \mathrm{H}-\mathrm{NMR}$ (DMSO-d6) $\delta$ (ppm): 5.19 (s, 2H, $\left.\mathrm{OCH}_{2}\right), 6.60$ (s, $1 \mathrm{H}, \mathrm{CH}$ of pyridine), 7.14-7.90 (m, 12H, aromatic $\mathrm{H}), 9.83\left(1 \mathrm{H}, \mathrm{NH}\right.$; exchangeable with $\left.\mathrm{D}_{2} \mathrm{O}\right) ;{ }^{13} \mathrm{C}-\mathrm{NMR}$ (DMSO-d6) $\delta(\mathrm{ppm})$ : 69.35, 115.42, 115.63, 115.67, 115.90, 128.97, 129.53, 129.95, 130.46, 130.54, 130.60, 130.85, 132.20, 132.31, 137.28, 151.09, 159.95, 161.17, 163.49, 164.20; MS, $m / z: 477\left[(\mathrm{M}+2)^{+}, 22.29 \%\right], 475\left(\mathrm{M}^{+}, 31.82 \%\right)$; Anal. Calcd. For $\mathrm{C}_{25} \mathrm{H}_{16} \mathrm{BrFN}_{2} \mathrm{O}_{2}$ (475.31): C, 63.17; H, 3.39; N, 5.89, Found: $\mathrm{C}, 63.08 ; \mathrm{H}, 3.22 ; \mathrm{N}, 5.95$.

6-(4-((4-Fluorobenzyl)oxy)phenyl)-4-(4-methoxyphenyl)-2-oxo-1,2-dihydropyridine-3-carbonitrile (5e)

Yield 77\%; m.p. 90-92 ${ }^{\circ} \mathrm{C}$; IR ( $\left.\mathrm{KBr}, \mathrm{cm}^{-1}\right)$ : $3234(\mathrm{NH}), 3078$ (CH aromatic), 2939 (CH aliphatic), $2214(\mathrm{CN}), 1651$ (CO); ${ }^{1} \mathrm{H}-\mathrm{NMR}$ (DMSO-d6) $\delta(\mathrm{ppm}): 3.83\left(\mathrm{~s}, 3 \mathrm{H}, \mathrm{OCH}_{3}\right), 5.25\left(\mathrm{~s}, 2 \mathrm{H}, \mathrm{OCH}_{2}\right), 6.83(\mathrm{~s}$, $1 \mathrm{H}, \mathrm{CH}$ of pyridine), $7.01-8.15(\mathrm{~m}, 12 \mathrm{H}$, aromatic $\mathrm{H}), 9.76\left(1 \mathrm{H}, \mathrm{NH}\right.$; exchangeable with $\left.\mathrm{D}_{2} \mathrm{O}\right) ;{ }^{13} \mathrm{C}-\mathrm{NMR}$ (DMSO-d6) $\delta$ (ppm): 55.84, 69.27, 114.85, 115.23, 115.64, 115.70, 115.95, 119.98, 130.49, 130.60, 130.68, 131.16, 131.25, 131.39, 161.18, 161.21, 161.78, 162.49, 163.55; MS, m/z: $426\left(\mathrm{M}^{+}, 24.92 \%\right)$; Anal. Calcd. For $\mathrm{C}_{25} \mathrm{H}_{19} \mathrm{FN}_{2} \mathrm{O}_{3}$ (426.44): C, 73.23; H, 4.49; N, 6.57, Found: C, 73.09; H, 4.35; N, 6.84.

\section{6-(4-((4-Fluorobenzyl)oxy)phenyl)-4-phenyl-2-thioxo-1,2-dihydropyridine-3-carbonitrile (6a)}

Yield 73\%; m.p. 110-112 ${ }^{\circ} \mathrm{C}$; IR ( $\left.\mathrm{KBr}, \mathrm{cm}^{-1}\right)$ : $3378(\mathrm{NH}), 3059$ (CH aromatic), 2932 (CH aliphatic), $2213(\mathrm{CN}) ;{ }^{1} \mathrm{H}-\mathrm{NMR}$ (DMSO-d6) $\delta(\mathrm{ppm}): 5.14\left(\mathrm{~s}, 2 \mathrm{H}, \mathrm{OCH}_{2}\right), 5.85\left(1 \mathrm{H}, \mathrm{NH}\right.$; exchangeable with $\left.\mathrm{D}_{2} \mathrm{O}\right)$, 7.06-7.58 $(\mathrm{m}, 7 \mathrm{H}$, aromatic $\mathrm{H}), 7.95(\mathrm{~s}, 1 \mathrm{H}, \mathrm{CH}$ of pyridine $), 8.03-8.28(\mathrm{~m}, 6 \mathrm{H}$, aromatic $\mathrm{H}) ;{ }^{13} \mathrm{C}-\mathrm{NMR}$ (DMSO-d6) $\delta$ (ppm): 69.35, 115.10, 115.67, 115.82, 128.77, 128.87, 129.03, 129.16, 129.29, 129.91, 130.45, 130.53, 133.50, 152.79, 159.82, 160.71, 161.08, 163.43; MS, $m / z$ : $412\left(\mathrm{M}^{+}, 24.66 \%\right)$; Anal. Calcd. For $\mathrm{C}_{25} \mathrm{H}_{17} \mathrm{FN}_{2} \mathrm{OS}$ (412.48): C, 72.80; H, 4.15; N, 6.79, Found: C, 72.92; H, 4.23; N, 6.82.

6-(4-((4-Fluorobenzyl)oxy)phenyl)-4-(4-fluorophenyl)-2-thioxo-1,2-dihydropyridine-3-carbonitrile (6b)

Yield 53\%; m.p. $114-116^{\circ} \mathrm{C}$; IR (KBr, cm $\left.{ }^{-1}\right)$ : $3303(\mathrm{NH}), 3072$ (CH aromatic), 2935 (CH aliphatic), $2213(\mathrm{CN}) ;{ }^{1} \mathrm{H}-\mathrm{NMR}$ (DMSO-d6) $\delta(\mathrm{ppm}): 5.21\left(\mathrm{~s}, 2 \mathrm{H}, \mathrm{OCH}_{2}\right), 6.75\left(1 \mathrm{H}, \mathrm{NH}\right.$; exchangeable with $\left.\mathrm{D}_{2} \mathrm{O}\right)$, 7.14-7.70 $(\mathrm{m}, 8 \mathrm{H}$, aromatic $\mathrm{H}), 7.85(\mathrm{~s}, 1 \mathrm{H}, \mathrm{CH}$ of pyridine $), 8.17-8.27(\mathrm{~m}, 4 \mathrm{H}$, aromatic $\mathrm{H}) ;{ }^{13} \mathrm{C}-\mathrm{NMR}$ (DMSO-d6) $\delta$ (ppm): 69.09, 115.48, 115.63, 115.87, 115.99, 116.24, 116.45, 129.44, 129.78, 130.48, 130.54, 131.52, 131.73, 131.82, 133.46, 153.60, 161.07, 163.50, 165.28, 167.54; MS, $m / z: 430$ ( $\left.\mathrm{M}^{+}, 83.68 \%\right)$; Anal. Calcd. For $\mathrm{C}_{25} \mathrm{H}_{16} \mathrm{~F}_{2} \mathrm{~N}_{2} \mathrm{OS}$ (430.47): C, 69.75; H, 3.75; N, 6.51, Found: $\mathrm{C}, 69.64 ; \mathrm{H}, 3.51 ; \mathrm{N}, 6.60$.

4-(4-Chlorophenyl)-6-(4-((4-fluorobenzyl)oxy)phenyl)-2-thioxo-1,2-dihydropyridine-3-carbonitrile (6c)

Yield 70\%; m.p. $92-93^{\circ} \mathrm{C}$; IR ( $\left.\mathrm{KBr}, \mathrm{cm}^{-1}\right): 3327(\mathrm{NH}), 3068$ ( $\mathrm{CH}$ aromatic), 2935 (CH aliphatic), $2215(\mathrm{CN}) ;{ }^{1} \mathrm{H}-\mathrm{NMR}$ (DMSO-d6) $\delta(\mathrm{ppm}): 5.09\left(1 \mathrm{H}, \mathrm{NH}\right.$; exchangeable with $\left.\mathrm{D}_{2} \mathrm{O}\right), 5.19\left(\mathrm{~s}, 2 \mathrm{H}, \mathrm{OCH}_{2}\right)$, $6.98-7.85(\mathrm{~m}, 8 \mathrm{H}$, aromatic $\mathrm{H}), 8.03(\mathrm{~s}, 1 \mathrm{H}, \mathrm{CH}$ of pyridine $), 8.07-8.27(\mathrm{~m}, 4 \mathrm{H}$, aromatic $\mathrm{H}) ;{ }^{13} \mathrm{C}-\mathrm{NMR}$ (DMSO-d6) $\delta$ (ppm): 69.13, 115.50, 115.64, 115.88, 129.18, 129.37, 129.50, 129.65, 129.76, 130.51, 130.57, $131.08,131.22,133.21,133.44,158.62,161.08,161.21,161.33,163.50 ; \mathrm{MS}, m / z: 448$ [(M+2) $\left.{ }^{+}, 4.96 \%\right], 446$ $\left(\mathrm{M}^{+}, 16.29 \%\right)$; Anal. Calcd. For $\mathrm{C}_{25} \mathrm{H}_{16} \mathrm{ClFN}_{2} \mathrm{OS}$ (446.92): C, 67.19; H, 3.61; N, 6.27, Found: $\mathrm{C}, 69.20 ; \mathrm{H}$, $3.55 ; \mathrm{N}, 6.34$.

4-(4-Bromophenyl)-6-(4-((4-fluorobenzyl)oxy)phenyl)-2-thioxo-1,2-dihydropyridine-3-carbonitrile $(6 \mathrm{~d})$ 
Yield 70\%; m.p. $75-77^{\circ} \mathrm{C}$; IR (KBr, cm $\left.{ }^{-1}\right)$ : $3305(\mathrm{NH}), 3062$ (CH aromatic), 2939 (CH aliphatic), $2206(\mathrm{CN}) ;{ }^{1} \mathrm{H}-\mathrm{NMR}$ (DMSO-d6) $\delta(\mathrm{ppm}): 5.18\left(\mathrm{~s}, 2 \mathrm{H}, \mathrm{OCH}_{2}\right), 7.13-7.26(\mathrm{~m}, 4 \mathrm{H}$, aromatic $\mathrm{H}), 7.47$ (s, $1 \mathrm{H}, \mathrm{CH}$ of pyridine), $7.52-8.19(\mathrm{~m}, 8 \mathrm{H}$, aromatic $\mathrm{H}), 8.59\left(1 \mathrm{H}, \mathrm{NH}\right.$; exchangeable with $\left.\mathrm{D}_{2} \mathrm{O}\right) ;{ }^{13} \mathrm{C}-\mathrm{NMR}$ (DMSO-d6) $\delta$ (ppm): 69.11, 115.13, 115.33, 115.50, 115.70, 115.88, 123.29, 129.46, 129.51, 130.50, 130.61, $131.26,131.53,132.09,133.17,155.81,160.75,162.52,162.59,162.75 ; \mathrm{MS}, m / z: 493\left[(\mathrm{M}+2)^{+}, 25.16 \%\right], 491$ $\left(\mathrm{M}^{+}, 28.39 \%\right)$; Anal. Calcd. For $\mathrm{C}_{25} \mathrm{H}_{16} \mathrm{BrFN}_{2} \mathrm{OS}$ (491.37): $\mathrm{C}, 61.11 ; \mathrm{H}, 3.28 ; \mathrm{N}, 5.70$, Found: $\mathrm{C}, 61.22 ; \mathrm{H}$, $3.35 ; \mathrm{N}, 5.75$.

6-(4-((4-Fluorobenzyl)oxy)phenyl)-4-(4-methoxyphenyl)-2-thioxo-1,2-dihydropyridine-3-carbonitrile (6e)

Yield 58\%; m.p. $183-185^{\circ} \mathrm{C}$; IR ( $\left.\mathrm{KBr}, \mathrm{cm}^{-1}\right)$ : $3377(\mathrm{NH}), 3078$ (CH aromatic), 2939 (CH aliphatic), $2214(\mathrm{CN}) ;{ }^{1} \mathrm{H}-\mathrm{NMR}$ (DMSO-d6) $\delta(\mathrm{ppm}): 3.85\left(\mathrm{~s}, 3 \mathrm{H}, \mathrm{OCH}_{3}\right), 5.19\left(\mathrm{~s}, 2 \mathrm{H}, \mathrm{OCH}_{2}\right), 5.27(1 \mathrm{H}, \mathrm{NH}$; exchangeable with $\left.\mathrm{D}_{2} \mathrm{O}\right), 7.04-7.54(\mathrm{~m}, 8 \mathrm{H}$, aromatic $\mathrm{H}), 7.70(\mathrm{~s}, 1 \mathrm{H}, \mathrm{CH}$ of pyridine $), 8.02-8.21(\mathrm{~m}, 4 \mathrm{H}$, aromatic H); ${ }^{13} \mathrm{C}-\mathrm{NMR}$ (DMSO-d6) $\delta$ (ppm): 55.86, 69.10, 114.59, 114.70, 114.79, 115.38, 115.64, 115.87, $129.59,130.47,130.55,130.71,130.93,133.60,157.12,160.75,161.08,161.21,163.53,163.61 ;$ MS, $m / z: 442$ $\left(\mathrm{M}^{+}, 15.54 \%\right)$; Anal. Calcd. For $\mathrm{C}_{26} \mathrm{H}_{19} \mathrm{FN}_{2} \mathrm{O}_{2} \mathrm{~S}$ (442.50): C, 70.57; H, 4.33; N, 6.33, Found: $\mathrm{C}, 70.50 ; \mathrm{H}$, $4.19 ; \mathrm{N}, 6.22$.

\subsection{Biological Activity}

\subsubsection{Drugs and Drug Treatments}

Compounds under investigation were dissolved in DMSO to make a stock solution. Solutol ${ }^{\circledR}$ HS15 is a nonionic solubilizer that consists of polyglycol mono- and di-esters of 12-hydroxystearic acid with approximately $30 \%$ of free polyethylene glycol for making the injection solutions.

\subsubsection{Cytotoxicity Evaluation}

Human cancer cells were obtained from Nawah Scientific Inc. (Mokatam, Cairo, Egypt). Cells were maintained in DMEM media containing $100 \mathrm{mg} / \mathrm{mL}$ streptomycin, 100 units $/ \mathrm{mL}$ penicillin, and $10 \%$ heat-inactivated fetal bovine serum in humified, $5 \%(v / v) \mathrm{CO}_{2}$ atmosphere at $37^{\circ} \mathrm{C}$.

Cell viability was estimated using the SRB assay. Aliquots of $100 \mu \mathrm{L}$ cell suspension $\left(5 \times 10^{3}\right.$ cells $)$ in 96-well plates were incubated in complete media for $24 \mathrm{~h}$. Cells were treated with a second aliquot of $100 \mu \mathrm{L}$ media containing various concentrations of the tested compounds $(0.01,0.1,1,10$, and $100 \mu \mathrm{M})$. After $72 \mathrm{~h}$, cells were fixed by replacing media with $15 \mu \mathrm{L}$ of $10 \%$ TCA and then incubated at $4{ }^{\circ} \mathrm{C}$ for $1 \mathrm{~h}$. After that, TCA solution was removed, and the cells were washed 5 times with distilled water. Aliquots of $70 \mu \mathrm{L}$ SRB solution $(0.4 \% w / v)$ were added and incubated in a dark place at room temperature for $10 \mathrm{~min}$. Plates were washed 3 times with $1 \%$ acetic acid and allowed to air dry overnight. Then, $150 \mu \mathrm{L}$ of TRIS $(10 \mathrm{mM})$ was added to dissolve protein-bound SRB stain. The absorbance was measured at $540 \mathrm{~nm}$ using BMG LABTECH ${ }^{\circledR}$-FLUO star Omega microplate reader (Ortenberg, Germany).

\subsubsection{Cell Cycle Analysis}

MDA-MB-231 cells (density $=4 \times 10^{6}$ cells by T 75 flasks) were treated with $\mathbf{5 c}$ and $\mathbf{5 e}$ at their IC50 concentrations for $24 \mathrm{~h}$. After that, cells were collected by trypsin and washed in saline buffered with phosphate. Then, they were fixed using ice-cold alcohol. Afterwards, cells were stained by a Cycle TESTTM PLUS DNA Reagent Kit (BD Biosciences, San Jose, CA, USA) according to the manufacturer's directions. The distribution of the cells in the cell cycle was calculated using a FACS Calibur flow cytometer (BD Biosciences, San Jose, CA, USA).

\subsubsection{Apoptotic Analysis}

MDA-MB-231 cells were plated in 24-well tissue culture plates. After $24 \mathrm{~h}$, compounds $\mathbf{5 c}$ and $\mathbf{5 e}$ were added at their $\mathrm{IC}_{50}$ concentrations. After $48 \mathrm{~h}$, cells that floated were collected from the medium. 
The adherent cells were separated using 0.05\% trypsin. After that, a 10\% FBS medium was added for inactivating trypsin. Following slow pipetting, the centrifugation of cells was done for $5 \mathrm{~min}$ at $1500 \times \mathrm{g}$. Then, the supernatant was discarded, and cells were then stained with double annexin V-fluorescein isothiocyanate in addition to propidium iodide (PI) staining following the manufacturer's directions. Analysis of the cells was investigated using a FACScan flow cytometer.

\subsubsection{Western Blotting Analysis}

MDA-MB-231 cancer cells were incubated with $5 \mathrm{c}$ and $5 \mathrm{e}$ at different concentrations $(1,5$, and $10 \mu \mathrm{M})$ for $48 \mathrm{~h}$. Afterwards, the medium was detached, and the cells were washed using PBS $(10 \mathrm{mmol} / \mathrm{L}, \mathrm{pH} 7.4)$. Then, the cells were incubated on cold lysis buffer $(50 \mathrm{mmol} / \mathrm{L}$ Tris- $\mathrm{HCl}$, $150 \mathrm{mmol} / \mathrm{L} \mathrm{NaCl}, 1 \mathrm{mmol} / \mathrm{L}$ EGTA, $1 \mathrm{mmol} / \mathrm{L}$ EDTA, $20 \mathrm{mmol} / \mathrm{L} \mathrm{NaF}, 100 \mathrm{mmol} / \mathrm{L} \mathrm{Na} 3 \mathrm{VO} 4,0.5 \%$ NP40, $1 \%$ Triton X-100, 1 mmol/L PMSF (pH 7.4)) and a freshly added cocktail inhibitor (Inhibitor Cocktail Set III, Calbiochem, La Jolla, CA) above ice for $30 \mathrm{~min}$. Then, MDA-MB-231 cells were collected and centrifuged at $12,000 \times g$ for $15 \mathrm{~min}$.

XIAp, Survivin, Livin, and cIAP1anti-mouse, anti-rabbit secondary antibodies, and GAPDH were purchased from Sigma-Aldrich, whereas the gel was obtained from BioRad. Polyacrylamide gels were moved to a nitrocellulose membrane in order to block in buffer $(7 \%$ nonfat dry milk/1\% Tween 20; in $20 \mathrm{mmol} / \mathrm{L}$ TBS (pH 7.6)) for $1 \mathrm{~h}$ and incubated for $2 \mathrm{~h}$ at room temperature with the suitable primary antibody in blocking buffer or overnight at $4{ }^{\circ} \mathrm{C}$; then, they were incubated with secondary antibody HRP conjugate. Finally, the blots analysis was done using the imaging system [39-41].

\subsection{Molecular Docking Study}

Molecular docking analysis was performed using MOE-Dock 2014.09. The chemical structures of $5 \mathbf{c}$ and $5 \mathbf{e}$ were sketched using Chemdraw and then imported to MOE, where they were exposed to energy minimization and conformational search. Now, their 3D conformers were docked into the survivin protein dimerization site (PDB code: 1E31). In the docking process, London dG was reserved for ranking and the GBVI/WSA dG was used for the scoring of the generated poses. Analysis and visualization of the results were performed using the "Ligand Interactions" tool to display the binding modes of these compounds in the survivin active site.

Supplementary Materials: The Supplementary Materials are available online, Figures S1-S36 contain the NMR charts for the synthesized compounds, Figures S37-S39 contain the cell cycle analysis for control and compounds $5 \mathbf{c}$ and 5e, Figures S40-S41 contain western blotting analysis for 5c and 5e.

Author Contributions: The listed authors contributed to this work as described in the following. R.S. and M.F.H. gave the concepts of the work. O.M.A.K., N.A., R.S. and M.F.H., interpreted the results, prepared the manuscript, read, and approved the final manuscript. All authors have read and agreed to the published version of the manuscript.

Funding: This research project was funded by the Deanship of Scientific Research, Princess Nourah bint Abdulrahman University, Riyadh, Saudi Arabia through the Program of Research Project Funding after Publication, grant No (41-PRF-A-P-12).

Conflicts of Interest: The authors declare no conflict of interest. The funders had no role in the design of the study; in the collection, analyses, or interpretation of data; in the writing of the manuscript, or in the decision to publish the results.

\section{References}

1. Siegel, R.L.; Mph, K.D.M.; Jemal, A. Cancer statistics, 2020. CA Cancer J. Clin. 2020, 70, 7-30. [CrossRef]

2. El-Wakil, M.H.; Ashour, H.M.; Saudi, M.N.; Hassan, A.M.; Labouta, I.M. Target identification, lead optimization and antitumor evaluation of some new 1,2,4-triazines as c-Met kinase inhibitors. Bioorg. Chem. 2017, 73, 154-169. [CrossRef]

3. Oltval, Z.N.; Milliman, C.L.; Korsmeyer, S.J. Bcl-2 heterodimerizes in vivo with a conserved homolog, Bax, that accelerates programed cell death. Cell 1993, 74, 609-619. [CrossRef]

4. Altieri, D.C. Survivin and IAP proteins in cell-death mechanisms. Biochem. J. 2010, 430, 199-205. [CrossRef] 
5. Findley, H.W.; Gu, L.; Yeager, A.M.; Zhou, M. Expression and Regulation of Bcl-2, Bcl-xl, and Bax Correlate With p53 Status and Sensitivity to Apoptosis in Childhood Acute Lymphoblastic Leukemia. Blood 1997, 89, 2986-2993. [CrossRef] [PubMed]

6. Mittal, R.; Jaiswal, P.K.; Goel, A. Survivin: A molecular biomarker in cancer. Indian J. Med. Res. 2015, 141, 389-397. [CrossRef] [PubMed]

7. Schimmer, A.D. Inhibitor of Apoptosis Proteins: Translating Basic Knowledge into Clinical Practice. Cancer Res. 2004, 64, 7183-7190. [CrossRef] [PubMed]

8. Chandele, A.; Prasad, V.; Jagtap, J.C.; Shukla, R.; Shastry, P.R. Upregulation of survivin in G2/M cells and inhibition of caspase 9 activity enhances resistance in staurosporine-induced Apoptosis. Neoplasia 2004, 6, 29-40. [CrossRef]

9. Abadi, A.H.; Abouel-Ella, D.A.; Lehmann, J.; Tinsley, H.N.; Gary, B.D.; Piazza, G.A.; Abdel-Fattah, M.A. Discovery of colon tumor cell growth inhibitory agents through a combinatorial approach. Eur. J. Med. Chem. 2010, 45, 90-97. [CrossRef] [PubMed]

10. Wang, Q.; Arnst, K.E.; Xue, Y.; Lei, Z.-N.; Ma, D.; Chen, Z.-S.; Miller, D.D.; Li, W. Synthesis and biological evaluation of indole-based UC-112 analogs as potent and selective survivin inhibitors. Eur. J. Med. Chem. 2018, 149, 211-224. [CrossRef] [PubMed]

11. Ling, X.; Cao, S.; Cheng, Q.; Keefe, J.T.; Rustum, Y.M.; Li, F. A Novel Small Molecule FL118 That Selectively Inhibits Survivin, Mcl-1, XIAP and cIAP2 in a p53-Independent Manner, Shows Superior Antitumor Activity. PLoS ONE 2012, 7, 45571. [CrossRef]

12. Peery, R.C.; Kyei-Baffour, K.; Dong, Z.; Liu, J.; Horn, P.D.A.; Dai, M.; Liu, J.-Y.; Zhang, J.-T. Synthesis and Identification of a Novel Lead Targeting Survivin Dimerization for Proteasome-Dependent Degradation. J. Med. Chem. 2020, 63, 7243-7251. [CrossRef]

13. Garg, H.; Suri, P.; Gupta, J.C.; Talwar, G.P.; Dubey, S. Survivin: A unique target for tumor therapy. Cancer Cell Int. 2016, 16, 1-14. [CrossRef]

14. Krepela, E.; Dankova, P.; Moravcikova, E.; Krepelova, A.; Prochazka, J.; Cermak, J.; Schützner, J.; Zatloukal, P.; Benkova, K. Increased expression of inhibitor of apoptosis proteins, survivin and XIAP, in non-small cell lung carcinoma. Int. J. Oncol. 2009, 35, 1449-1462. [CrossRef] [PubMed]

15. Kasof, G.M.; Gomes, B.C. Livin, a Novel Inhibitor of Apoptosis Protein Family Member. J. Biol. Chem. 2000, 276, 3238-3246. [CrossRef] [PubMed]

16. Xiao, M.; Li, W. Recent Advances on Small-Molecule Survivin Inhibitors. Curr. Med. Chem. 2015, 22, 1136-1146. [CrossRef] [PubMed]

17. Quispe, P.A.; Lavecchia, M.; León, I.E. On the discovery of a potential survivin inhibitor combining computational tools and cytotoxicity studies. Heliyon 2019, 5, 02238. [CrossRef] [PubMed]

18. Malki, A.; Mohsen, M.O.; Aziz, H.; Rizk, O.H.; Shaban, O.; El-Sayed, M.; Sherif, Z.A.; Ashour, H.M.; Shaaban, O. New 3-Cyano-2-Substituted Pyridines Induce Apoptosis in MCF 7 Breast Cancer Cells. Molecules 2016, 21, 230. [CrossRef]

19. Ghosh, P.S.; Manna, K.; Banik, U.; Das, M.; Sarkar, P. Synthetic strategies and Pharmacology of 2-oxo-3-cyanopyridine derivatives. Int. J. Pharm. Pharm. Sci. 2014, 6, 39-42.

20. Ibrahim, T.M.; Ernst, C.; Lange, A.; Hennig, S.; Boeckler, F.M. Small-Molecule Intervention At The Dimerization Interface Of Survivin By Novel Rigidized Scaffolds. Drug Des. Dev. Ther. 2019, 13, 4247-4263. [CrossRef]

21. Chettiar, S.N.; Cooley, J.V.; Park, I.-H.; Bhasin, D.; Chakravarti, A.; Li, P.-K.; Li, C.; Jacob, N.K. Design, synthesis and biological studies of Survivin Dimerization Modulators that prolong mitotic cycle. Bioorg. Med. Chem. Lett. 2013, 23, 5429-5433. [CrossRef] [PubMed]

22. Jerde, T.; Zhang, J.; Pili, R.; Safa, A.; Sullivan, W. Optimization of Survivin Dimerization Inhibitors for the Treatment of Docetaxel-Resistant Prostate Cancer. Ph.D. Thesis, Indiana University, New Delhi, India, 2020.

23. ElHameid, M.K.A.; Ryad, N.; My, A.-S.; Mohammed, M.; Ismail, M.; El Meligie, S.; Al-Shorbagy, M.Y. Design, Synthesis and Screening of 4,6-Diaryl Pyridine and Pyrimidine Derivatives as Potential Cytotoxic Molecules. Chem. Pharm. Bull. 2018, 66, 939-952. [CrossRef]

24. Sabour, R.; Harras, M.F.; Mehany, A.B. Design, synthesis, cytotoxicity screening and molecular docking of new 3-cyanopyridines as survivin inhibitors and apoptosis inducers. Bioorg. Chem. 2020, 94, 103358. [CrossRef]

25. Trivedi, A.R. Synthesis and biological evaluation of some new pyrimidines via a novel chalcone series. Arkivoc 2008, 2008, 131. [CrossRef] 
26. Harras, M.F.; Sabour, R. Design, synthesis and biological evaluation of novel 1,3,4-trisubstituted pyrazole derivatives as potential chemotherapeutic agents for hepatocellular carcinoma. Bioorg. Chem. 2018, 78, 149-157. [CrossRef] [PubMed]

27. Abdelaziz, M.E.; El-Miligy, M.M.; Fahmy, S.M.; Mahran, M.A.; Hazzaa, A.A. Design, synthesis and docking study of pyridine and thieno[2,3-b] pyridine derivatives as anticancer PIM-1 kinase inhibitors. Bioorg. Chem. 2018, 80, 674-692. [CrossRef] [PubMed]

28. Altalbawy, F.M.A. Synthesis and Antimicrobial Evaluation of Some Novel Bis- $\alpha$, $\beta$-Unsaturated Ketones, Nicotinonitrile, 1,2-Dihydropyridine-3-carbonitrile, Fused Thieno[2,3-b]pyridine and Pyrazolo[3,4-b]pyridine Derivatives. Int. J. Mol. Sci. 2013, 14, 2967-2979. [CrossRef]

29. Skehan, P.; Storeng, R.; Scudiero, D.; Monks, A.; McMahon, J.; Vistica, D.; Warren, J.T.; Bokesch, H.; Kenney, S.; Boyd, M.R. New Colorimetric Cytotoxicity Assay for Anticancer-Drug Screening. J. Natl. Cancer Inst. 1990, 82, 1107-1112. [CrossRef]

30. Allam, R.M.; Al-Abd, A.M.; Khedr, A.; Sharaf, O.A.; Nofal, S.M.; Khalifa, A.E.; Mosli, H.A.; Abdel-Naim, A.B. Fingolimod interrupts the cross talk between estrogen metabolism and sphingolipid metabolism within prostate cancer cells. Toxicol. Lett. 2018, 291, 77-85. [CrossRef]

31. Qi, J.; Dong, Z.; Liu, J.; Peery, R.C.; Zhang, S.; Liu, J.-Y.; Zhang, J.-T. Effective Targeting of the Survivin Dimerization Interface with Small-Molecule Inhibitors. Cancer Res. 2016, 76, 453-462. [CrossRef]

32. Chantalat, L.; Skoufias, D.A.; Kleman, J.-P.; Jung, B.; Dideberg, O.; Margolis, R.L. Crystal Structure of Human Survivin Reveals a Bow Tie-Shaped Dimer with Two Unusual $\alpha$-Helical Extensions. Mol. Cell 2000, 6, 183-189. [CrossRef]

33. Verdecia, M.A.; Huang, H.; Dutil, E.; Kaiser, D.A.; Hunter, T.; Noel, J.P. Structure of the human anti-apoptotic protein survivin reveals a dimeric arrangement. Nat. Genet. 2000, 7, 602-608. [CrossRef]

34. Agashe, V.R.; Shastry, M.C.R.; Udgaonkar, J.B. Initial hydrophobic collapse in the folding of barstar. Nat. Cell Biol. 1995, 377, 754-757. [CrossRef] [PubMed]

35. Lins, L.; Brasseur, R. The hydrophobic effect in protein folding. FASEB J. 1995, 9, 535-540. [CrossRef]

36. Kubota, H. Quality Control Against Misfolded Proteins in the Cytosol: A Network for Cell Survival. J. Biochem. 2009, 146, 609-616. [CrossRef] [PubMed]

37. Molecular Operating Environment (MOE). Chemical Computing Group Inc., 2014. Available online: http://www.chemcomp.com (accessed on 23 September 2020).

38. Ma, Y.-T.; Fan, H.-F.; Gao, Y.-Q.; Zhang, A.-L.; Gao, J.; Li, H. Natural Products as Sources of New Fungicides (I): Synthesis and Antifungal Activity of Acetophenone Derivatives Against Phytopathogenic Fungi. Chem. Biol. Drug Des. 2013, 81, 545-552. [CrossRef]

39. Chamcheu, J.C.; Afaq, F.; Syed, D.N.; Siddiqui, I.A.; Adhami, V.M.; Khan, N.; Singh, S.; Boylan, B.T.; Wood, G.S.; Mukhtar, H. Delphinidin, a dietary antioxidant, induces human epidermal keratinocyte differentiation but not apoptosis: Studies in submerged and three-dimensional epidermal equivalent models. Exp. Dermatol. 2013, 22, 342-348. [CrossRef]

40. Chamcheu, J.C.; Loriè, E.P.; Akgül, B.; Bannbers, E.; Virtanen, M.; Gammon, L.; Moustakas, A.; Navsaria, H.; Vahlquist, A.; Törmä, H. Characterization of immortalized human epidermolysis bullosa simplex (KRT5) cell lines: Trimethylamine N-oxide protects the keratin cytoskeleton against disruptive stress condition. J. Dermatol. Sci. 2009, 53, 198-206. [CrossRef]

41. Chamcheu, J.C.; Adhami, V.M.; Esnault, S.; Sechi, M.; Siddiqui, I.A.; Satyshur, K.A.; Syed, D.N.; Dodwad, S.-J.M.; Chaves-Rodriquez, M.-I.; Longley, B.J.; et al. Dual Inhibition of PI3K/Akt and mTOR by the Dietary Antioxidant, Delphinidin, Ameliorates Psoriatic Features In Vitro and in an Imiquimod-Induced Psoriasis-Like Disease in Mice. Antioxid. Redox Signal. 2017, 26, 49-69. [CrossRef]

Publisher's Note: MDPI stays neutral with regard to jurisdictional claims in published maps and institutional affiliations. 